\title{
The Content Analysis of the School Textbooks from the Viewpoint of the Aesthetic Dimensions with an Emphasis on the Qur'anic Beauties
}

\author{
- Dawood Tahmasb-zada Sheikhlar ${ }^{1}$-Azada Sahebi Alamdari ${ }^{2}$ = Mohsen Diba'i Saber ${ }^{3}$
}

- Objective: the present study aims at analyzing the content of school textbooks from the viewpoint of aesthetic dimensions and parameters with an emphasis on the Qur'anic beauties.

- Method: the present study is of practical type with a quantitative approach. Its method for gathering and analysis of data is of content analysis type. The statistical society of the study was the content of the textbook of the 'Heavenly Gifts' in primary schools in 1399-1400 SH school year. The statistical sample of the study consisted of the textbooks entitled the 'Heavenly Gifts' in the primary school. The tool for gathering data was the researchermade checklist for the parameters of aestheticism. For analyzing data, we used descriptive statistics and Shannon entropy.

- Findings: the findings showed that in the group of material beauties, 17 cases were for beauty of nature, 14 cases for beauty of animals, 6 cases for beauty of the sky, and 2 cases for the beauty of human and human artifacts. In the group of spiritual beauties, 38 cases were for beauty of the faith, 17 cases for beauty of knowledge, 11 cases for beauty of forgiveness and forbearance, 10 cases for beauty of one's intention, 4 cases for beauty of patience and endurance, and no case for beauty of wisdom. The results of Shannon entropy showed that weighting coefficient (Wj) was 271 for human's beauty, 142 for beauty of the sky, 189 for animals' beauty, 125 for nature's beauty, zero for beauty of colors, and 271 for beauty of humans' artifacts. Similarly, the Wj was 331 for patience and endurance, zero for beauty of wisdom, 182 for beauty of knowledge, 294 for beauty of intention, 0.074 for beauty of forgiveness and forbearance, and 115 for beauty of the faith. Besides, the highest use of rhetorical beauty in the Qur'an was for question with 26 cases of frequency.

- Conclusion: we can conclude that in the textbooks entitled the 'Heavenly Gifts' in primary schools, not all dimensions of material, spiritual, and rhetorical beauties have been paid attention to equally.

Keywords: Content Analysis, Aesthetics, Material Beauty, Spiritual Beauty, Rhetorical Beauty, Quran

Citation: Dawood Tahmasb-zada Sheikhlar,Azada Sahebi Alamdari, Mohsen Diba'i Saber. (2021). The Content Analysis of the School Textbooks from the Viewpoint of the Aesthetic Dimensions with an Emphasis on the Qur'anic Beauties, Applied Issues in Islamic education, 6(2): 55-86.

Received: 2021/05/02

Accepted: 2021/07/01

1. Corresponding Author: An Associate Professor of Curriculum development; Department of Educational Sciences, College of Educational Sciences and Psychology, Tabriz University, Tabriz, Iran.

E-mail: d.tahmaseb@tabrizu.ac.ir. iD 000-0001-7344-9931.

2. MA Student of Curriculum development, Department of Educational Sciences, College of Educational Sciences and Psychology, Tabriz University, Tabriz, Iran

E-mail: a_sahebi@tabrizu.ac.ir. (iD) 000-0002-6936-8407.

3. Assistant Professor of Curriculum development, Department of Educational Sciences, College of Humanities, Shahed University, Tehran, Iran

E-mail: m.dibaei@gmail.com. (iD) 000-0001-5061-2011. 



\section{تحليل محتثواى كتناب داى درسى

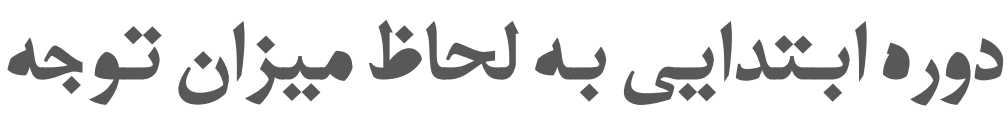

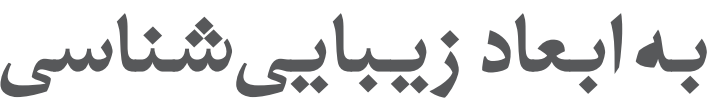

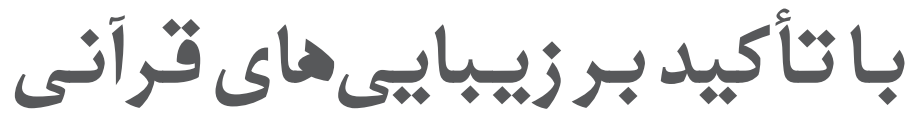

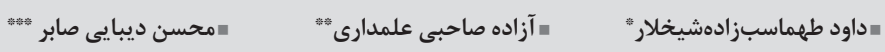

\section{Q숑}

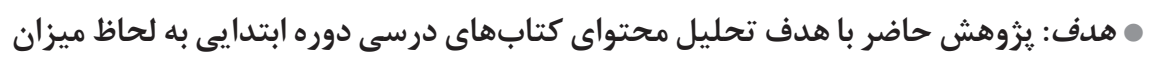

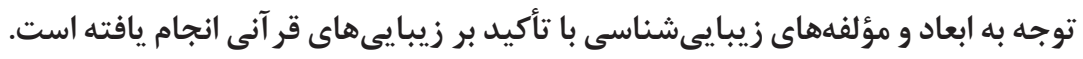

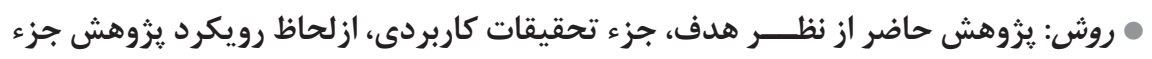

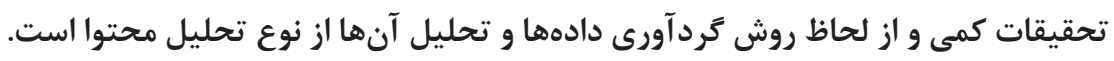

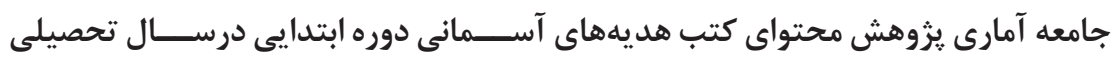

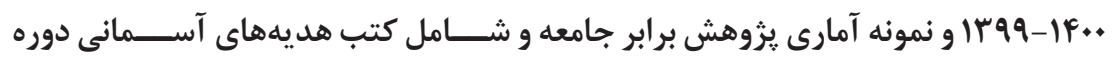

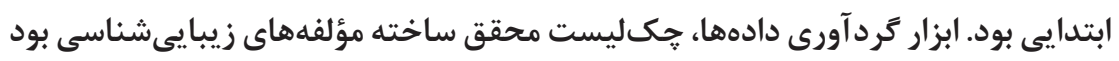

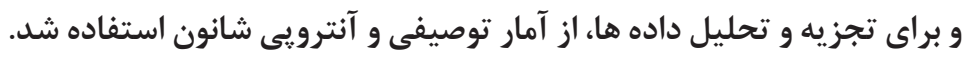

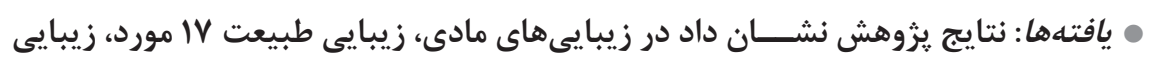

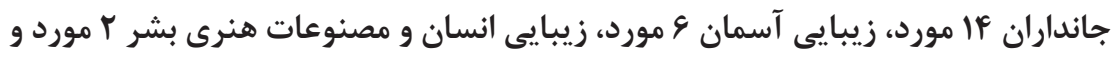

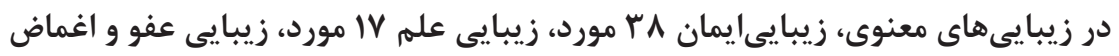

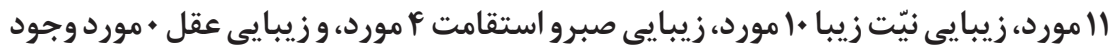

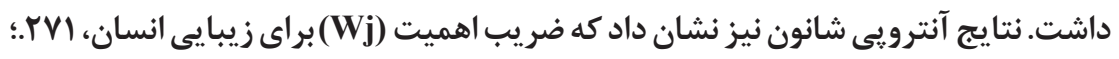

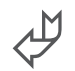

* نويسنده مسئول: دانشيار برنامهريزى درسى، گروه علوم تربيتى، دانشكده علوم تربيتى و روانشناسى، دانشخاه تبريز، تبريز، ايران. E-mail: d.tahmaseb@tabrizu.ac.ir. (iD 000-0001-7344-9931

*** دانشجوى كارشناسى ارشد برنامهريزى درسى، گروه علوم تربيتى، دانشكده علوم تربيتى و روانشناسى دانشكاه تبريز، تبريز، ايران. E-mail: a_sahebi@tabrizu.ac.ir. (D) 000-0002-6936-8407

$$
\text { ***** استاديار برنامهريزى درسى، گروه علوم تربيتى، دانشكده علوم انسانى، دانشگاه شاهد، تهران، ايران. }
$$

E-mail: m.dibaei@gmail.com. (iD) 000-0001-5061-2011 


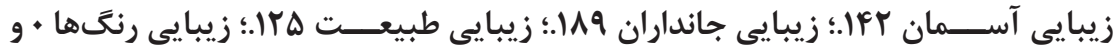

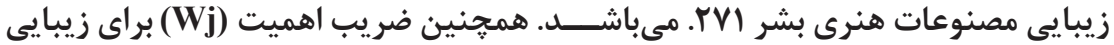

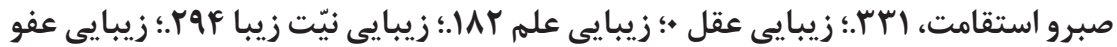

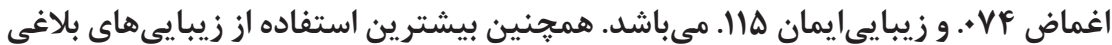

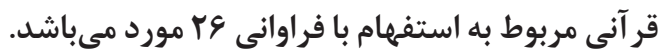
•نتا يج: بنابراين مى توان نتيجه كرفت كه در كتابهاى درسى هديه هاى آسمانى دوره ابتداى

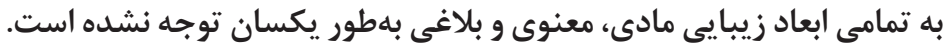

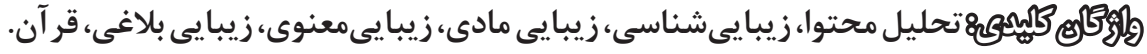

\section{مغندم}

تعليم و تربيت بهعنوان يك نهاد تربيتى و آموزشى كه مسئوليت تعليم علوم و تربيت شهروندى را به عهده دارد؛ بايستى به تمامى ابعاد وجودى انسان توجه نمايد. ولى نگاهى به تاريخ تعليم و تربيت كشورها نشان مىدهد كه سيستم آموزشى آنها در بعد آموزشى لهى و شـــناختى هدفمند عمل مى كند و ساير ابعاد وجودى انسان يا به فراموشى سيردهـه يا اگر هم ديده شده خيلى جشمخير و هدفمند نيست؛ درحالى كه مهرمترين هدف تعليمم و تربيت، كشــف نقاط قوت درونى هر فرد و كمك به او در شناسايى توانايىهاى ذهنى و عملى و كثف دنياى ييرامون خود مىباشد. تعليهم و تربيت عمومى ما اغلب معلمان و دانشآموزان را آموزش مى دهند تا بخوانند، بنويسند، بهطور تحليلى تفكر كنند، شمارش بكنـند و به شــيوههاى متفاوتى به توانايىهاى خود دســت يابند؛ اما جيزى كه كمتر به آن توجه مى شــود استعداد، خلاقيت، عواطف و احساسات و توانايى، زيبايىشناختى و...

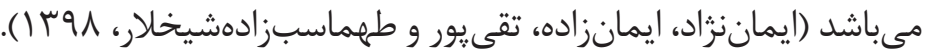
يكى از ابعاد مورد غفلت نظامهاى آموزشى، بعد عاطفى فراگيران مىباشد. علىرغم اينكه هم فيلســوفان تعليم و تربيت و هم متخصصان علوم تربيتى ازجمله روانشناسان تربيتى و رشد، اهميتاين موضوع را به شيوههاى ممكن روشن ساختهاند ولى باز هم در عمل و هنغام برنامهريزى درســى و آموزش، اين بعد را مورد بىتوجهى و بىمهرى قرار دادهاند. بىشك يكى از موضوعات بحثانگيز و مهمم در اين زمينه توجه برنامه درسى به زيبايى و زيبايىشناسى است (طهماسبزادهشيخلار، سوس (). 


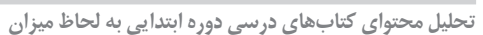

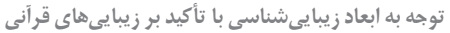

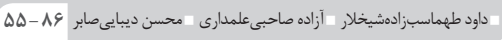

درك و دريافت زيبايى قدمتى به درازاى پِيدايش انســان به روى كره خاكى دارد. از

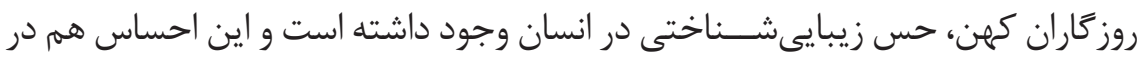

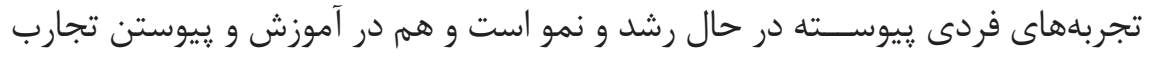

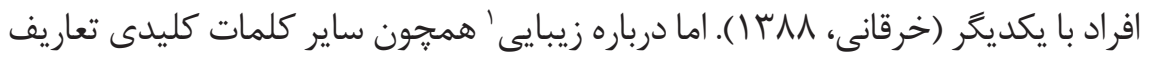

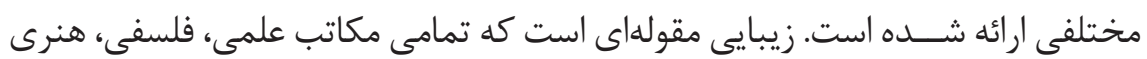

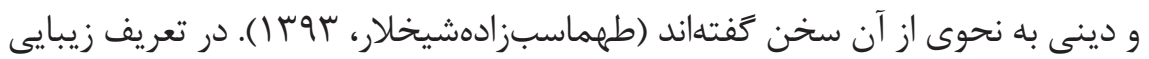

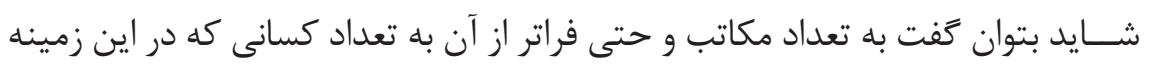

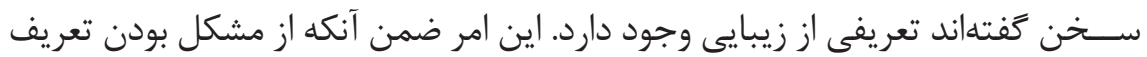

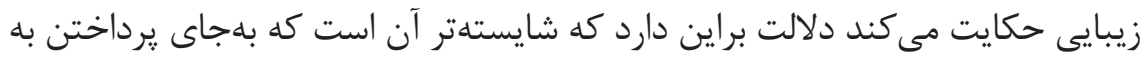

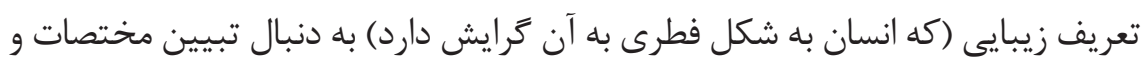

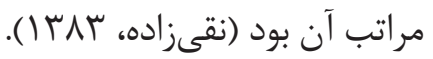

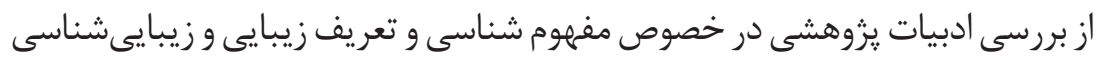

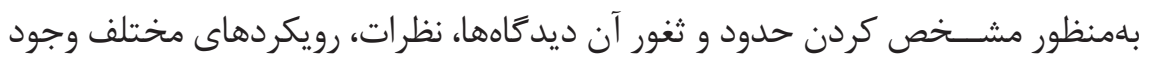

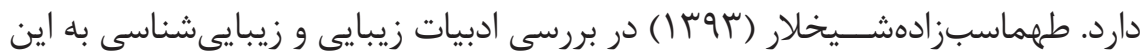

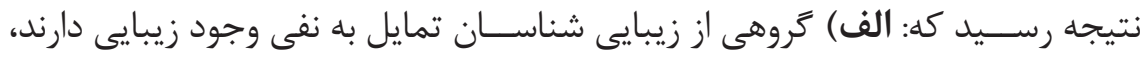

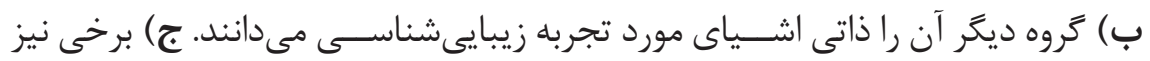

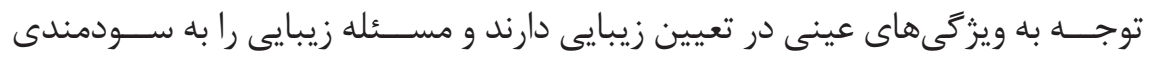

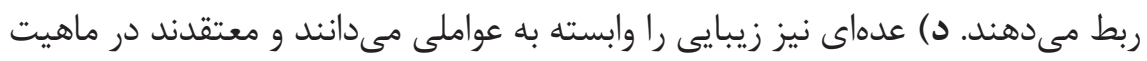

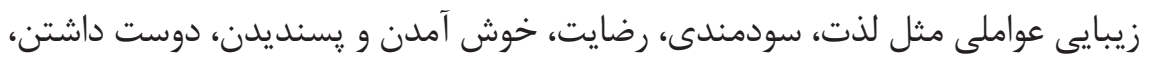

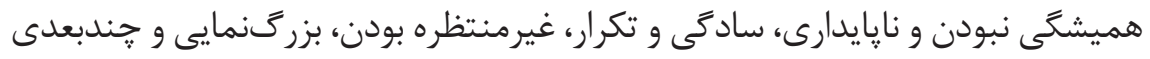

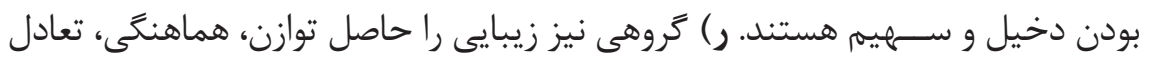

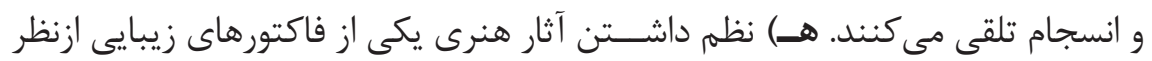

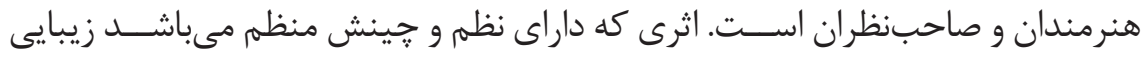

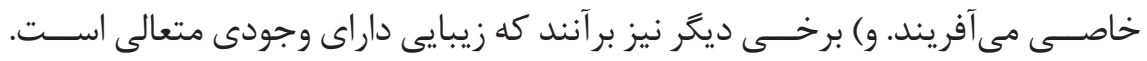

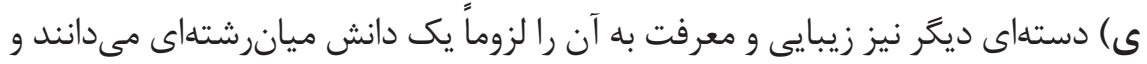

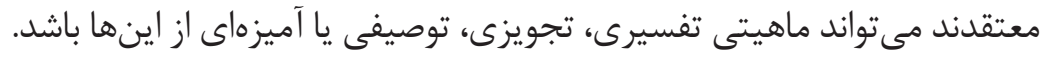


اين رويكرد ميانرشتهاى' به تربيت زيبايىشناسى اين اطمينان را مىدهد كه هيج مســـوليت منحصر به فردى براى هيتجكدام از ســـرفصلهاى درسى يا قلمروهاى برنامه درســى وجود ندارد و تجربه زيبايىشناســى حوزه تخصصى منحصربافرد هنر نيست و مى توان آن را در تمامى بخشهاى تجربه يافت. مطالعات آكادميك، زيبايىشناسى را با هنر و انسان گرايى مرتبط مىسازد (Gale, 2005). به نظر Gale، زيبايىشناسى مى تواند يك نقش بسيار مهم و حساس در ســاير رشتهها داشته باشد. براى نمونه، رياضى دانان

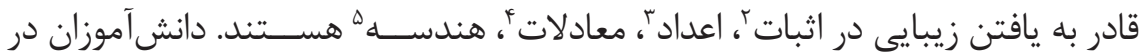

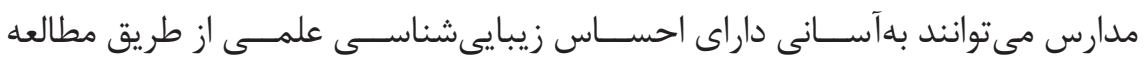
طبيعت، زمينشناســى، سبكهاى زندكَى، اقيانوسشناسى، اخترشناسى و از اين قبيل

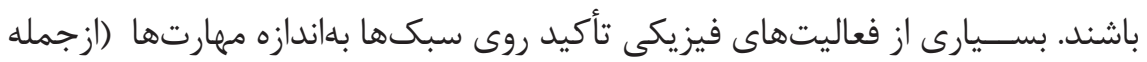
زيمناستيك و شنا) دارد (Jacobs, 2009). عليرغم اهميت رويكرد زيبايىشناسى در برنامه درسى، تصور مىشود كه در ادبيات تعليم و تربيت و برنامه درســى، زيبايىشناسى در نتيجه توجه فلاسفه و صاحبنظران غربى درباره اهميت و نقش هنر و زيبايى در تعليم و تربيت مورد توجه اســت ولى اين مفاهيم در تربيت اسلامى همجنان مغفول مانده است: زيبايىشناسى اگرجه از موقعيت مهمى در فلاسفه و جهانبينى اسلامى برخوردار است اما به دلايل مختلف تاريخى، علمى و اجتماعى تضعيفشده و در سطح مباحث نظرى و ادبى باقىمانده و تقريباً هيج نقشى در علوم اســلامى و انسانى بهخصوص تربيت اسلامى در عصر ما ايفا نكرده است. (عليق، • وس ( ) اين در حالى است ادبيات ملى و اسلامى ما سرشار از تجربههاى تربيتى زيبايى شناسانه است (طرماسبزادهشيخلار، سوس|). از بررسى سير تحول برنامه درسـى در طول تاريخ مىتوان استنباط كرد كه برنامه درسى از رويكردهاى شناختى سنتى كه عامل عواطف رادخالت نمى دهد تأثير يذيرفته و از رويكردهاى معاصر كه به عواطف و احساسات در شناخت توجه داشته غافل مانده است. به عبارتى رويكردهاى برنامه درسى از ييشرفت و دستاوردهاى علوم شناختى عقبمانده 


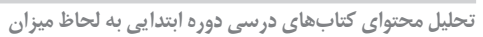

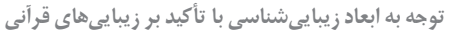

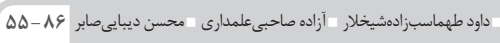

اسـت و در حال حاضر از سنت شناخت كرايى تأثير يذيرفته ولى از يافتههاى جديد آن

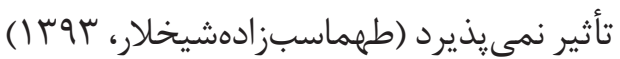

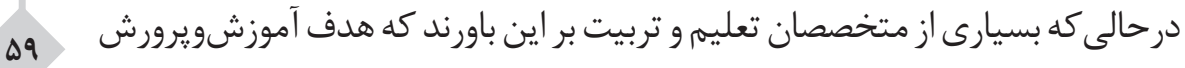

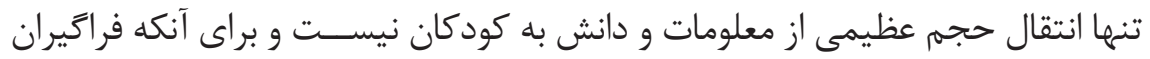

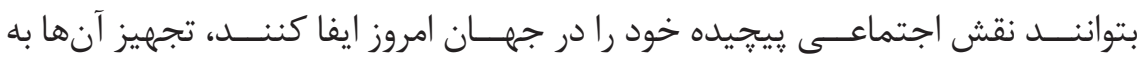

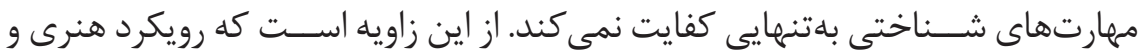

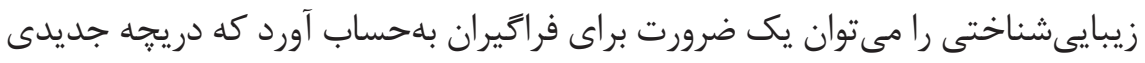

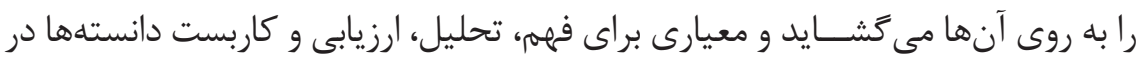

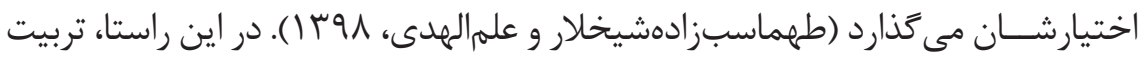

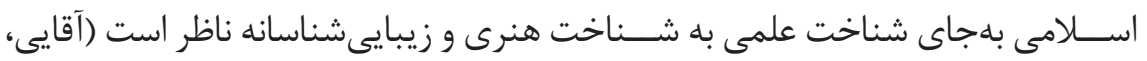

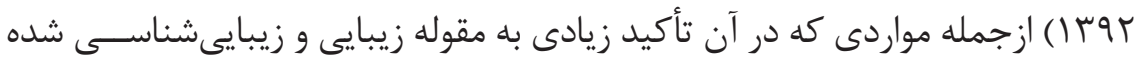

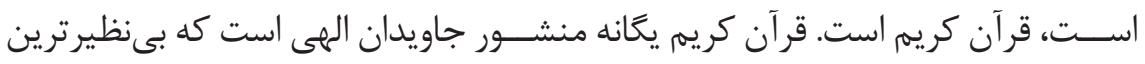

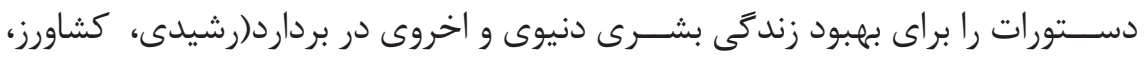

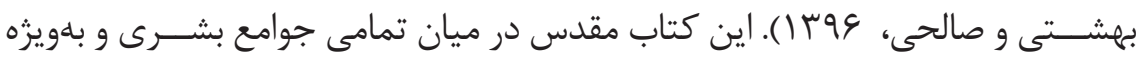

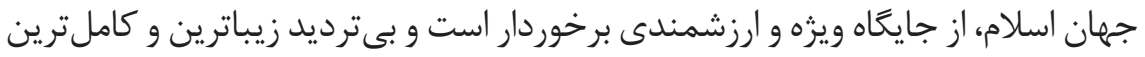

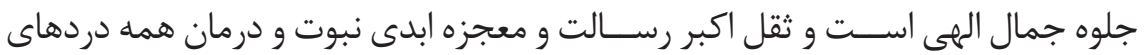

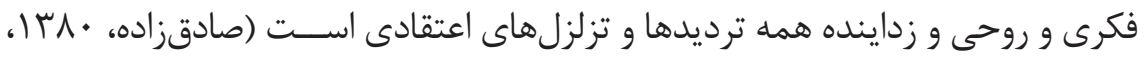

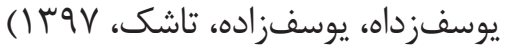
قرآن كه كتاب تربيت است به زيبايى توجه كرده است. اين كتاب آسمانى بهمنزله كتاب كتاب

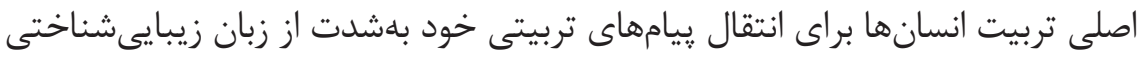

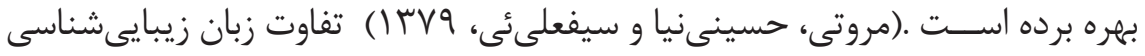

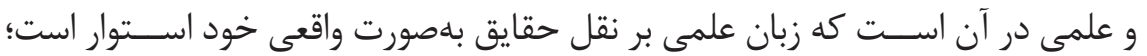

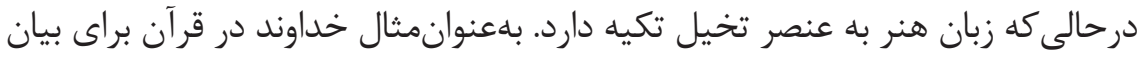

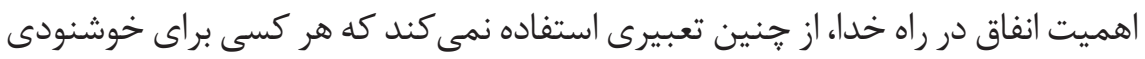

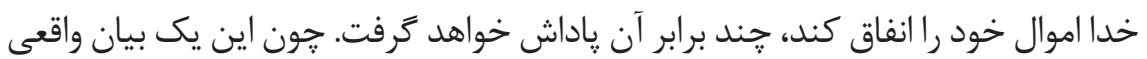

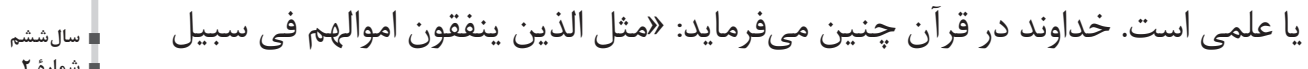

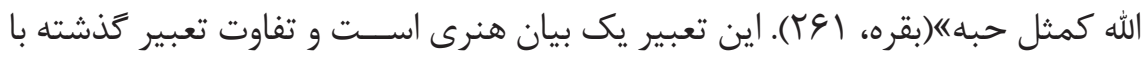


اين تعبير، ايجاد يا افزون يك رابطه جديد ميان لانفاق" و "دانه گندم" است (به نقل از

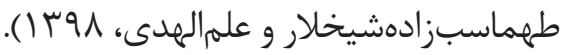
در فطرت انســان كه خليفه خداوند در زمين اسـت حس زيبايى دوستى و زيبايى جويى نهاده شده و انسان بهطور فطرى به دنبال زيبايى و نيازمند زيبايى است. در اسلام زيبايى همگام با عقل و فطرت اســت، زيبايى و زيبايى جويى امر مطلوبى شمرده شده، به آن دعوت شــده و حتى محروم كردن مردم از آن توبيخ شــده است. ازآنجاكه انسان داراى فطرت است و قرآن نيز كتاب تكوين و هدايت بهحساب مى آيد، يس مىتوان كَت آيات الهى (قرآن) براى رشـــ، هدايت و شكوفايى فطرت انسانى نازلشده است. از اينرو تربيت و هدايت فطرت، هدف اصلى آفرينش بهحســاب مىآيد (طهماسبزادهشيخلار و

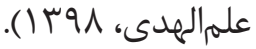
بـــا توجه به اهميت بعد تربيت زيبايـىشــــاختى فراخيران، دميـــنـن روح به محتواى كتابهاى درسى و زنده كردن موضوع و محتوايى كه مهلم و قابل تعليم تشخيص دادهشده، با رويكرد زيبايىشناســى ممكن اســـ؛ زيرا زيبايى از ديدگاه اسلامى درجه كاملترى از حيات و زندگى است و علائم آن بهصورت منظم و معنادارى يعنى توازن شغلى يا هندسى و تعادل و تناسب و... خود را نشان مىدهد؛ اما ذات زيبايى در حيات ريشه دارد و معنا را القاء

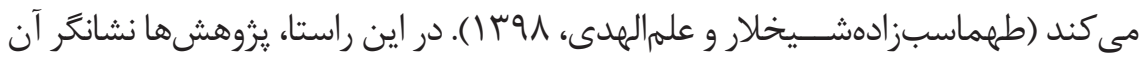
است كه اصول و ارزشهاى دينى مىتواند از طريق كتب درسى انتقال يابد و زيبايىشناسى نيز از اين قاعده مستثنى نيست (Niemi \& Junn, 1993). بطور كلى زيبايى در قرآن به دو دسته زيبايىهاى محسوسات (مادى) و زيبايىهاى معنويات تقسيم مىشود: مالف) زيبايیىهاى مادى (محسوسات): زيبايى است كه با قواى ظاهرى انسان درك مىشــود و در جمادات، حيوانات و نباتات، آســمان، زمين و درياها و غيره هويداست و شامل زيبايى انسان، زيبايى آسمان، زيبايى جانداران، زيبايى طبيعت،

$$
\text { زيبايى رنت ها، زيبايى مصنوعات هنرى و زيباى بشر است. }
$$

○) زيبايىهاى معنوى: زيباىهايى كه با قوه خيال انسان درك مىشوند؛ نظير زيبايى فصاحت و بلاغت كه در قرآن كريم و سخنان ائمه اطهار عليههمالسلام فراوان به جشم مى خورد. اين زيبايى با قوه عقل انسان نيز درك مىشود و شامل صبر و 
استقامت، زيبايى عقل، زيبايى علم، نيت زيبا، زيبايى عفو و اغماض، زيبايىايمان

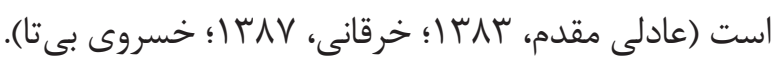

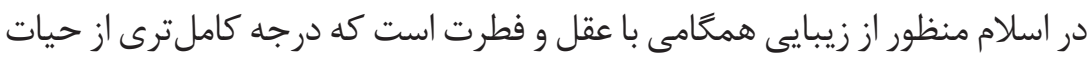

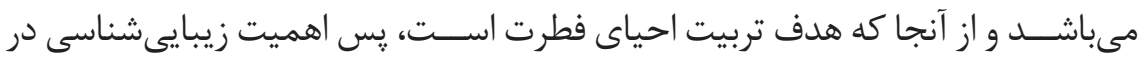

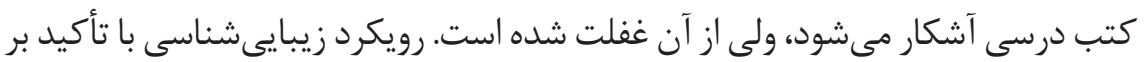

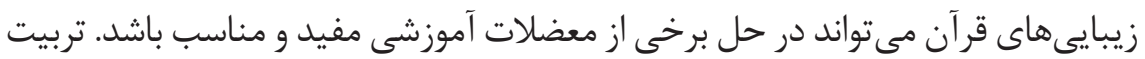

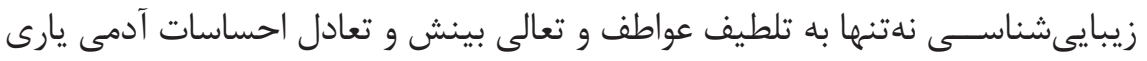

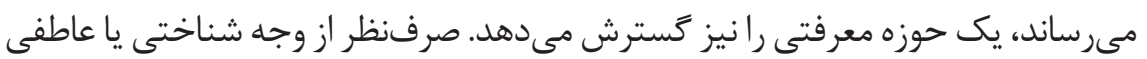

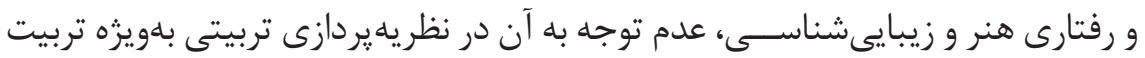

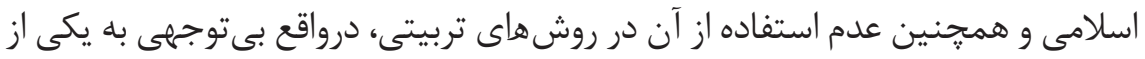

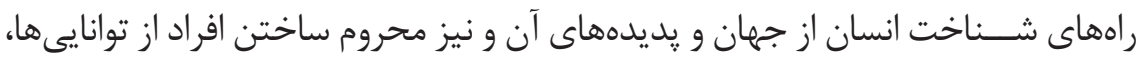

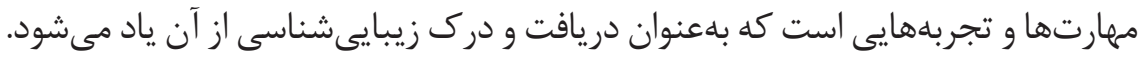

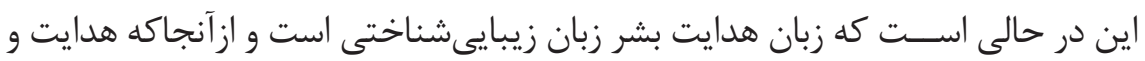

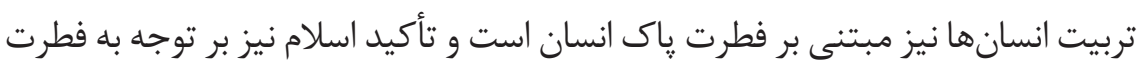

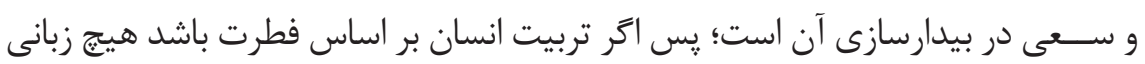

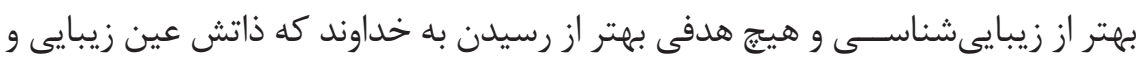

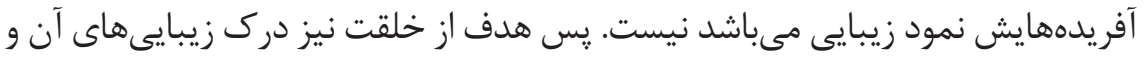

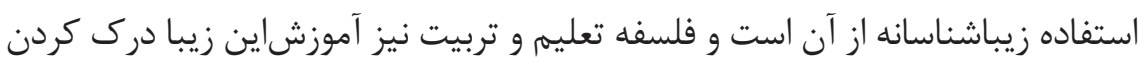

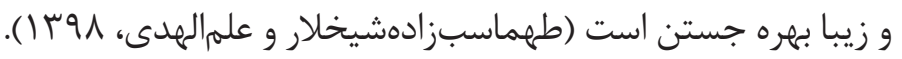

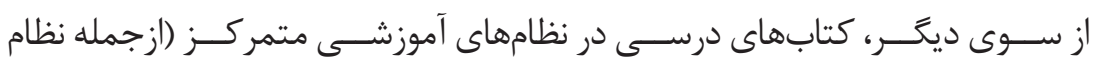

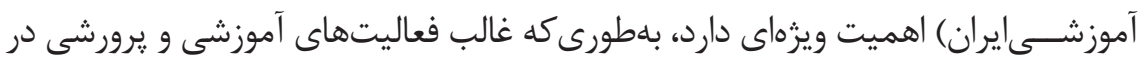

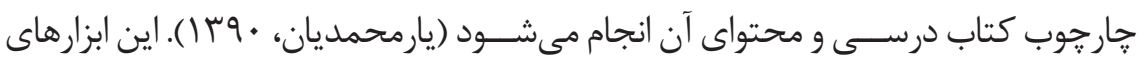

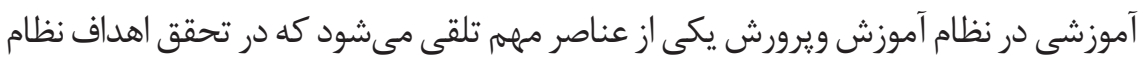

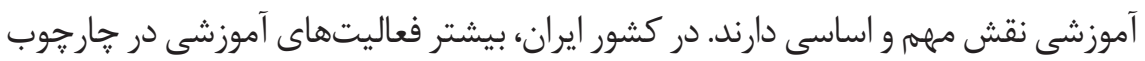

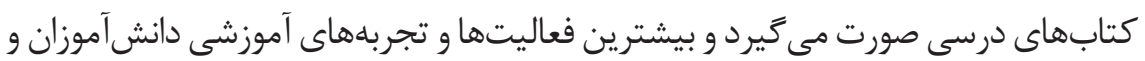

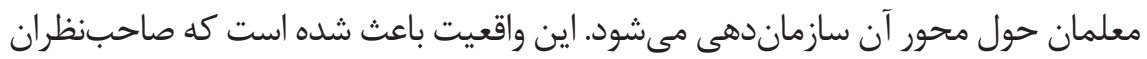

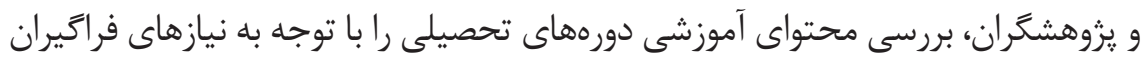




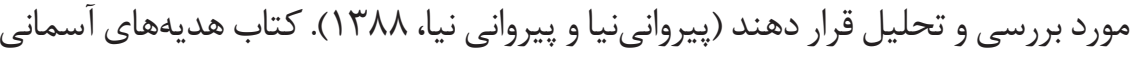

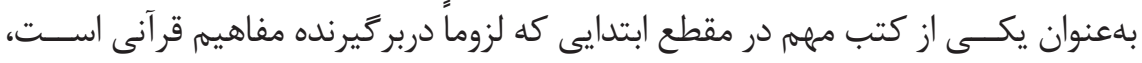
مى تواند نقش مهمم و بسزايى در تربيتى زيبايىشناختى و توجه به مؤلفههاى زيبايىشناختى با رويكرد قرآنى داشـــهـ باشـــــــا لذزوهش حاضر به بررسى و تحليل محتواى كتابهاى

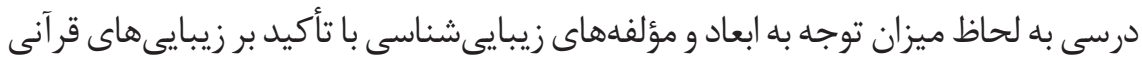
مى يردازد و ســؤال اصلى يزوهشاين اســت كه به جه ميزان به اين مؤلفهها در اين كتب درسى هديههاى آسمانى يرداخته شده است. به عبارتى سؤال هاى اصلى يزوهش عبارتند از:

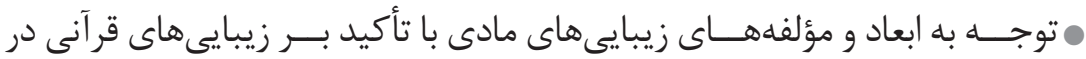

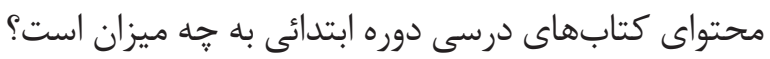
ه توجـــه به ابعاد و مؤلفههاى زيبايـىهاى معنوى با تأكيــد بر زيبـايـهاى قرآنى در محتواى كتابهاى درسى دوره ابتدائى به جُه ميزان است؟ ه توجه به زيبايىهاى بلاغى قرآنى(تشبيه، استعاره، كنايه، مبالغه، استفهام، حذف، تكرار، واجآرايى) در محتواى كتابهاى درسى دوره ابتدائى به جهه ميزان است؟

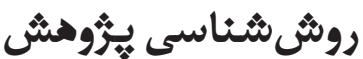

يزوهـــش حاضر از نظر هدف، جزء تحقيقات كاربردى، از لحاظ رويكرد يثرهش جزء تحقيقات كمى، به لحاظ ماهيت، توصيفى و از لحاظ روش گردآورى دادهها و تحليل آنها از نوع تحليل محتوا اســت. اكثر تحليلهاى محتوا در تعليهم و تربيت شامل جمعآورى دادهها درباره جنبههاى مختلف ييامهاى رمزگردانى شــده در محصول ارتباطات است. تحليل محتوا بهعنوان يك روش تحقيق داراى مراحل زير اســت: انتخاب جامعه آمارى؛ معيــار توصيف؛ انتخاب يك طبقهبندى بر اســاس معيار توصيــف؛ تعيين واحد ثبت؛

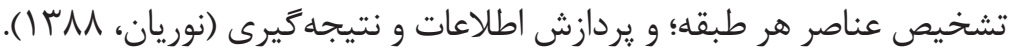
در ايــن :زئوهش، محتواى كتب هديههاى آســمانى مقطع ابتدايى ســال تحصيلى

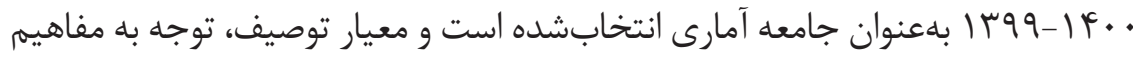
زيبايىشناســانه قر آنى مى باشد. نمونه آمارى يزوهش شــامل كتب هديههاى آسمانى

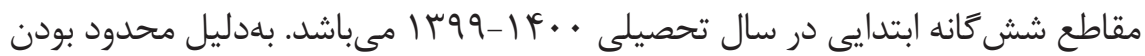
حجم جامعل، حجم نمونه برابر با حجم جامعه بود. 
تحليل محتواى كتابهاى درسى دوره ابتدايى به لحاظ ميزان

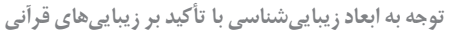

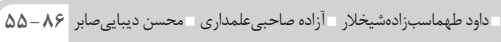

جدول ا. مشخصات كتب هديههاى آسمانى مقطع ابتدايى

\begin{tabular}{|c|c|c|c|c|c|c|}
\hline مجموع & شڤيهم & هنجمَ & جايارم & سوميه & دوم بايه & كتاب ها \\
\hline$\Delta q r$ & 115 & ITA & ITA & ITA & 99 & تعداد صفحه \\
\hline q & $1 \mathrm{~V}$ & IV & 19 & $r$. & $r$. & تعداد درس \\
\hline
\end{tabular}

بـــا توجه بـــه اينكـه روش تحقيق حاضــــر از نوع تحليل محتواســت، بنابراين جهرت

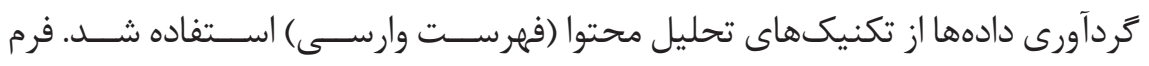

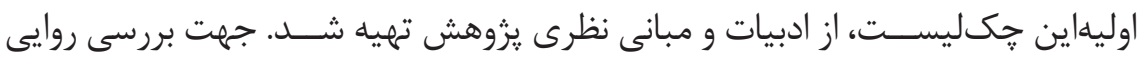
آن، جُكليست تهيهشده در اختيار رنج نفر از صاحبنظراناين حوزه (اساتيد رشتههاى قرآنى، اساتيد زبان و ادبيات عربى، زبانشناسى، برنامهريزى درسى و هنر) براى تغيير و

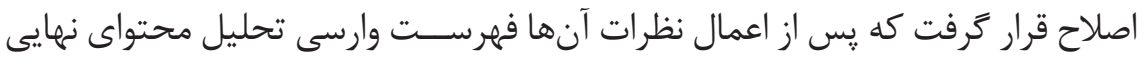

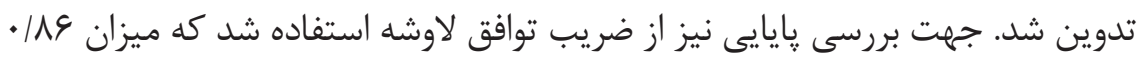
به دست آمد. واحد تحليل و بررسى در اين يزوهش، متون (كلمات، جملات و عبارتها)، تصاوير، يرسشها و فعاليتهاى كتب هديههاى آسمانى مقطع ابتدايى بود.

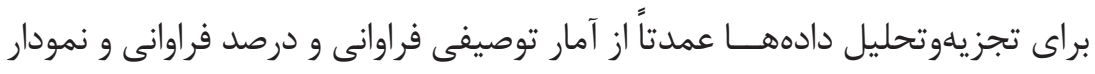
استفاده شد؛ اما براى آزمودن ســؤالات تحقيق از آمار استنباطى آنترويى شانون جهت بررسى درجه اهميت هريك از ابعاد و مؤلفهها استفاده شد. روش آنترويى شانون برگرفته از تئورى سيستمها است و در بحث تحليل محتوا، نگاه جديدى به يردازش دادههاست. براساساين روش تحليل دادهها بسيار قوىتر و معتبرتر مىشود. در نظريه اطلاعات، آنترويى شاخصى براى اندازهَيرى عدم اطمينان است كه با بـان

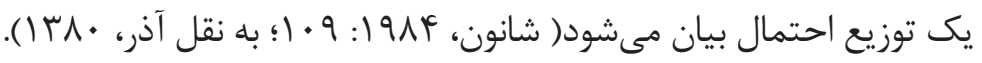

\section{جهـت انجام آنترويى شانون در تحليل محتوا:}

هـ ابتـــدا فراوانــى هريكى از مقولههاى شناســـايى شـــده بر اســاس تحليل محتوا، مشـــص شـــد و ماتريس فراوانى هاى مورد نظر به هنجار شد. براى اين منظور از 
ه در مرحلهى دوم بار اطلاعاتى هر مقوله محاسبه شد:

$a=\frac{1}{L_{n(a)}}$

$$
E_{j}=-k \sum\left[n_{i j} \operatorname{Ln}\left(n_{i j}\right)\right]
$$

ه در مرحلهى ســـوم ضريب اهميت هر مقوله محاســـبه شد. هر مقوله كه داراى بار اطلاعاتى بيشترى باشد، از درجه اهميت بيشترى برخوردار است: $w_{j}=\frac{E_{j}}{\sum_{l}^{m} E_{j}}$

$$
\begin{aligned}
& \text { n }
\end{aligned}
$$

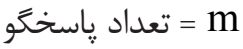

$$
\begin{aligned}
& \text { j } \\
& \text { E }=E_{j} \\
& \text { i }
\end{aligned}
$$

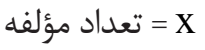

$$
\begin{aligned}
& \text { Ln } \\
& \text { ضريب اهميت هر مقوله }=W_{j}
\end{aligned}
$$

هر مقولهاى كه داراى بار اطلاعاتى بيشــترى باشـــد بايد از درجهى اهميت (W

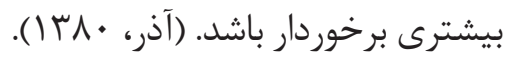

\begin{tabular}{|c|c|c|c|c|c|c|}
\hline مصنوعات هنرى بشر & ر رنى ها & طبيعت & جانداران & آسمان & انسان & زيبايى مادى \\
\hline ايمان & عفو اغماض & نيّيت زيبا & علم & عقل ع & صبر و استقامت & زيبايى معنوى \\
\hline واج آرايى & استفهام & تشخيص & كنايه & استعاره & تشبيه & زيبايى بلاغى \\
\hline
\end{tabular}

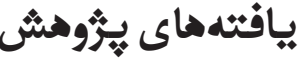

در بررســى ادبيات و مبانى نظرى موضوع يزوهش، دوازده مؤلفه زيبايىشناســى با

$$
\text { تأكيد بر زييايىهاى قرآن شناسايى شد. }
$$

جدول r. جدول ابعاد و مؤلفههاى زيبايىشناسى با تأكيد بر زيبايىهاى قر آنى

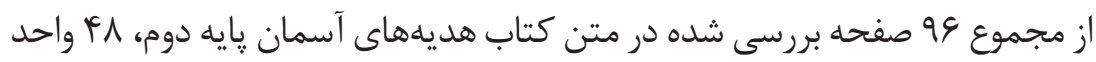
تحليل شناســايى و فراوانى هر مؤلفه و كليد وازه مربوطه در جدول زير نشان داده شده است. در جدول r-r فراوانى مؤلفهها و كليد وازههاى مؤلفهها با ذكر مثال براى هر كدام 


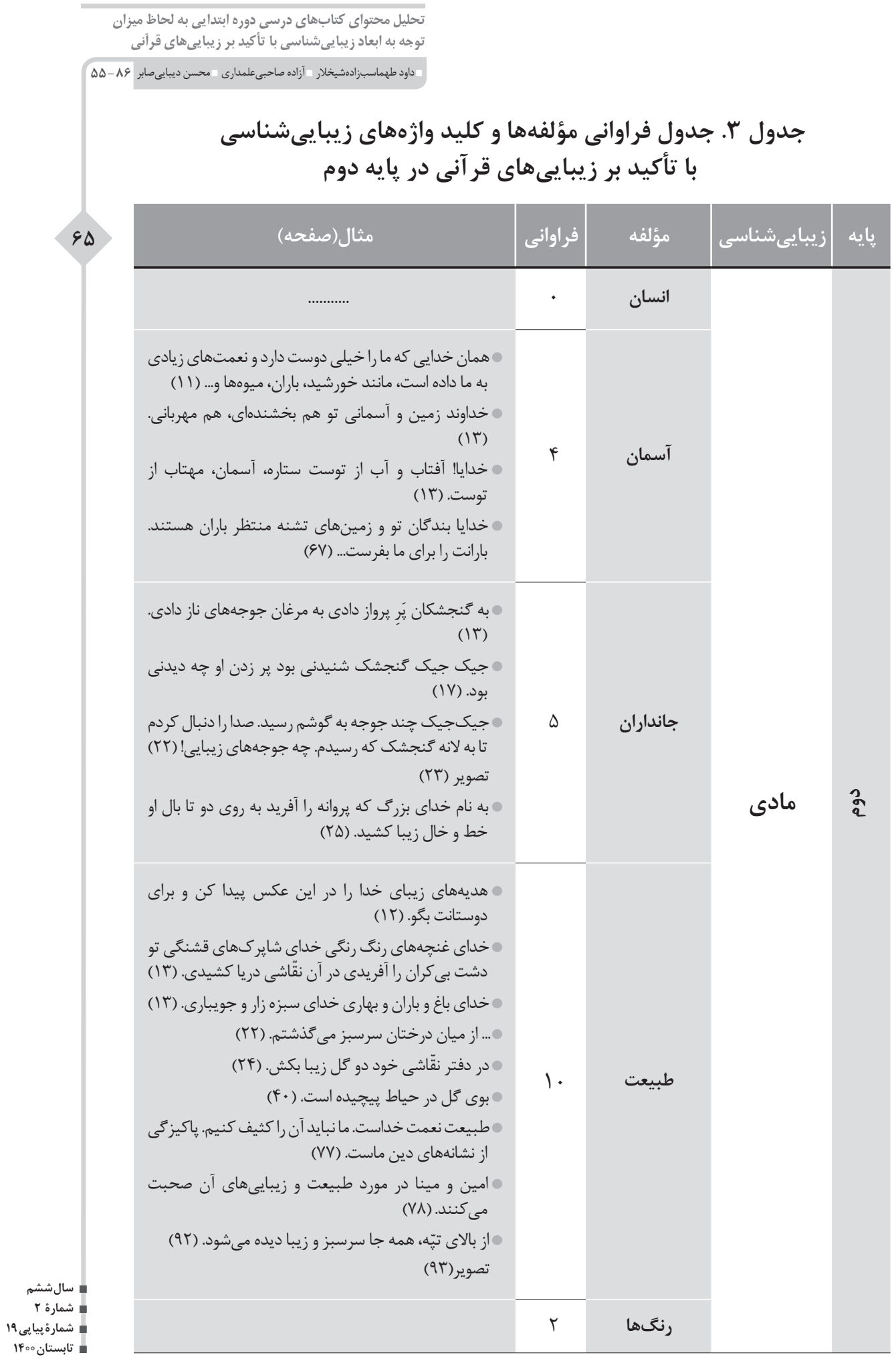


فصلنامه (علمى_يثوهشى)

مسائل كاربردى تعليمو تربيت اسلامي

جدول س. (ادامه)

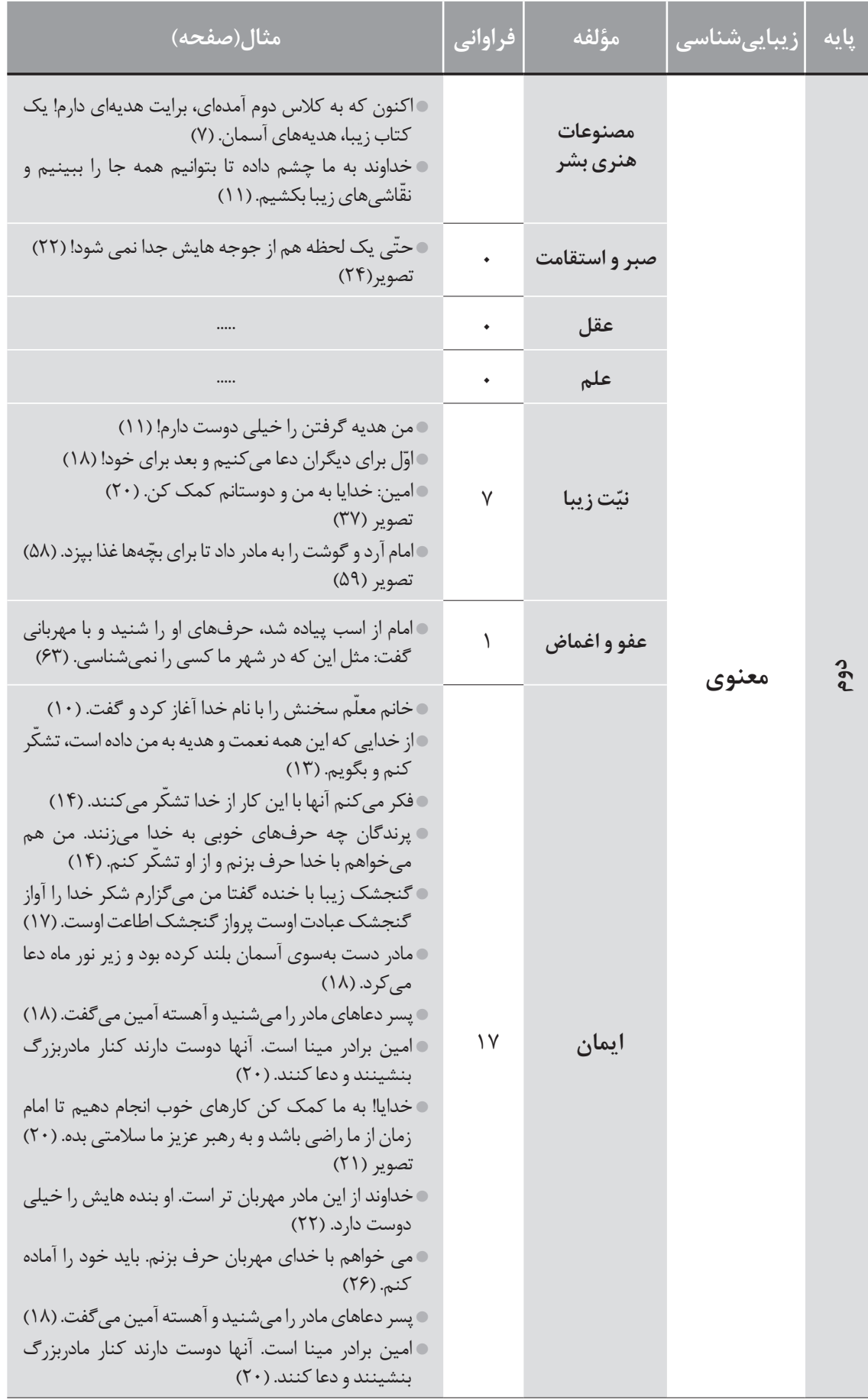


تحليل محتواى كتابهاي درسى دوره ابتدايى به لحاظ ميزان

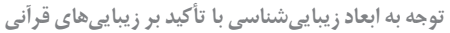

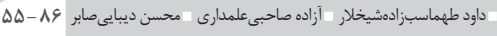

جدول r. (ادامه)

مثال (صفحها)

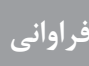

مؤلفه زيبايى شناسى

بإيه

خ خدايا! به ما كمك كن كارهاى خوب انجام دهيم تا امام

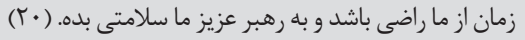

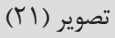

خداوند از اين مادر مهربان تر است. او بنده هايش راخيلى داري

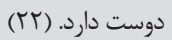

مى خواهم با خداى مهربان حرف بزنم. بايد خود را آماده

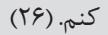

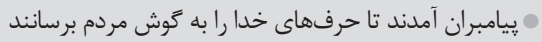

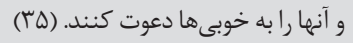

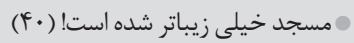

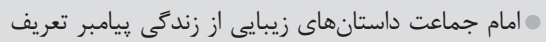

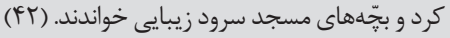

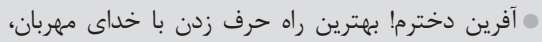
خواندن نماز است. (هذرما بهترين

نماز خواندن جه خوب و زيباست ياد خداوند فروغ دل ها.

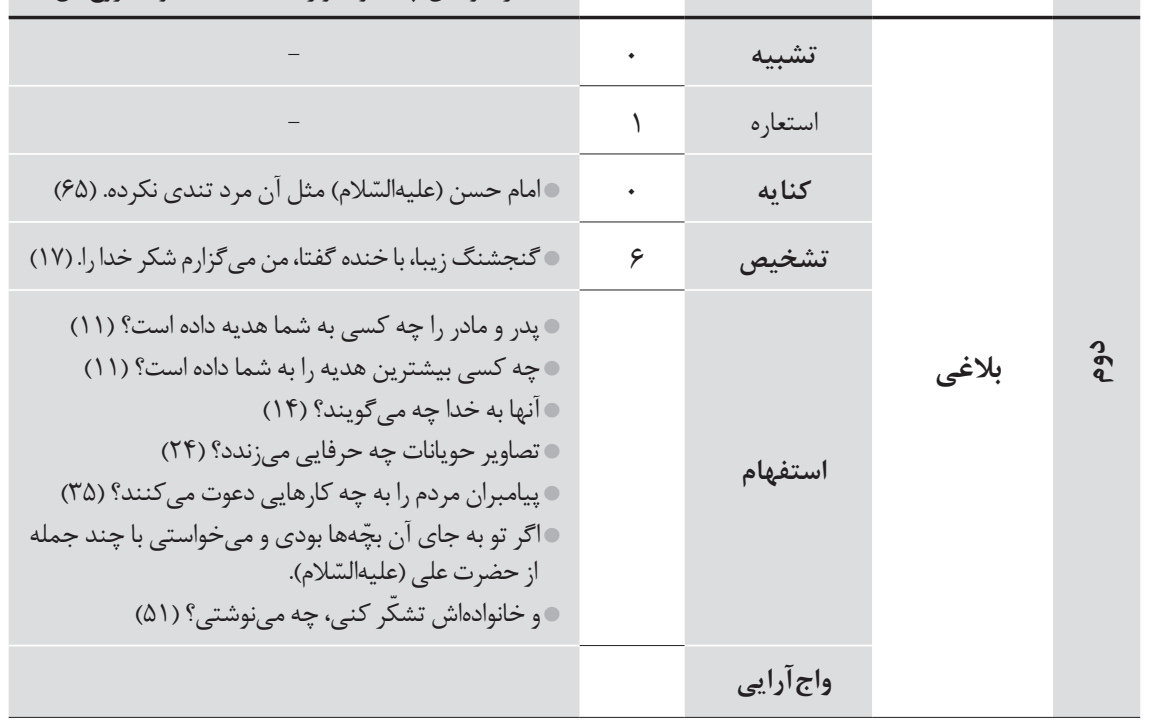

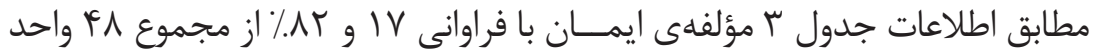

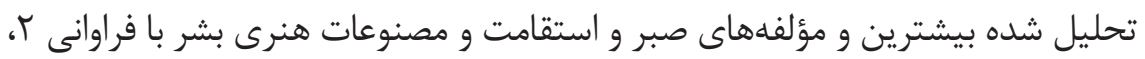

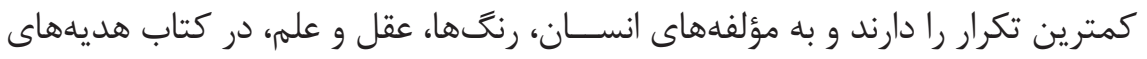


از مجموع \\| صفحه بررسى شده در متن كتاب هديههاى آسمان يايه سوم، \| واحد تحليل

شناسـايى و فراوانى هر مؤلفه و كليدوازمى مربوطه در جدول زير نشان داده شده است. در جدول F فراوانى مؤلفهها و كليدوازههاى مؤلفهها با ذكر مثال براى هر كدام در يايه ســوم آورده

جدول F. جدول فراوانى مؤلفهها و كليد وازههاى زيبايیىشناسى با تأكيد بر زيبايىهاى قر آنى در هايه

\begin{tabular}{|c|c|c|c|c|}
\hline مثال(صفحه) & فراوانى & مؤلفه & زيبايىشناسى & هايه \\
\hline ................. & - & انسان & \multirow{6}{*}{ مادى } & \multirow{6}{*}{$\frac{3}{2}$} \\
\hline 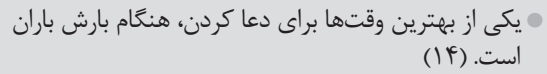 & 1 & آسمان & & \\
\hline .................. & - & جانداران & & \\
\hline$\ldots \ldots \ldots . .$. & - & طبيعت & & \\
\hline ................... & r & رنَها & & \\
\hline ............. & • & هنرى بشر & & \\
\hline 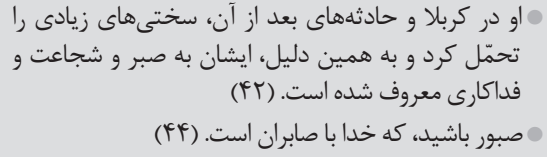 & r & صبر و استقامت & \multirow{4}{*}{ معنوى } & \multirow{4}{*}{$\underset{2}{3}$} \\
\hline & - & عقل & & \\
\hline 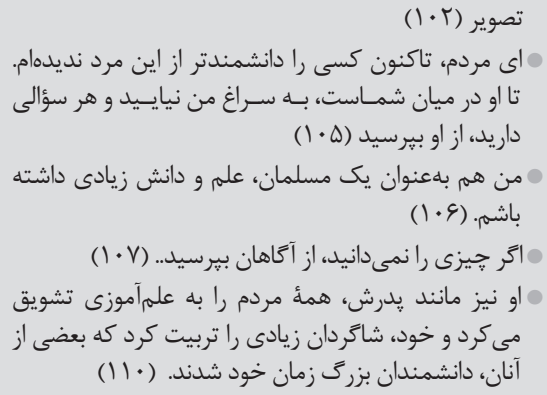 & $\Delta$ & علهم & & \\
\hline 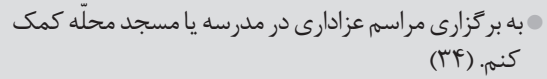 & & نيّت زيبا & & \\
\hline
\end{tabular}


تحليل محتواى كتابهاي درسى دوره ابتدايى به لحاظ ميزان

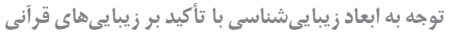

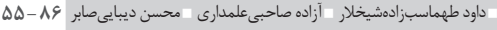

جدول F. (ادامه)

مثال(صفحه)

\begin{tabular}{|c|c|c|c|}
\hline فراوانى & مؤلفه & زيبايىشناسى & $d$ \\
\hline
\end{tabular}

هامن خودم تصميسم كرفتم با شمـا كه مرا نمى كمناسيد،

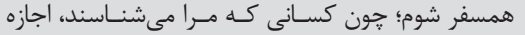

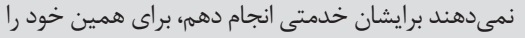

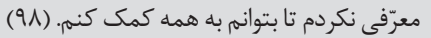

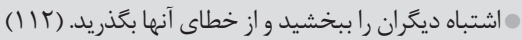

ت تنها كسى را بيرستيد كه آفريدگار شما و آفريدًار زمين

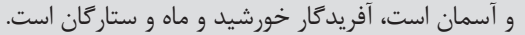

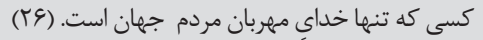

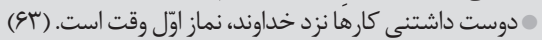

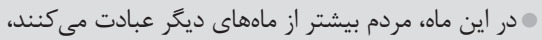

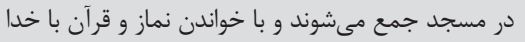

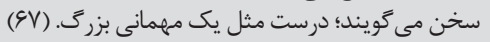

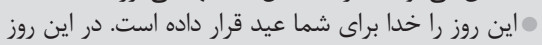

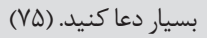

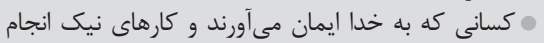

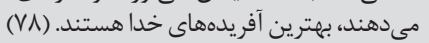

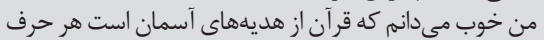

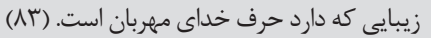

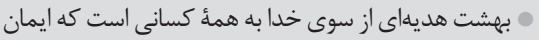
مى آورند و كارهاى خوب انجام مي دهند. (I I (I)

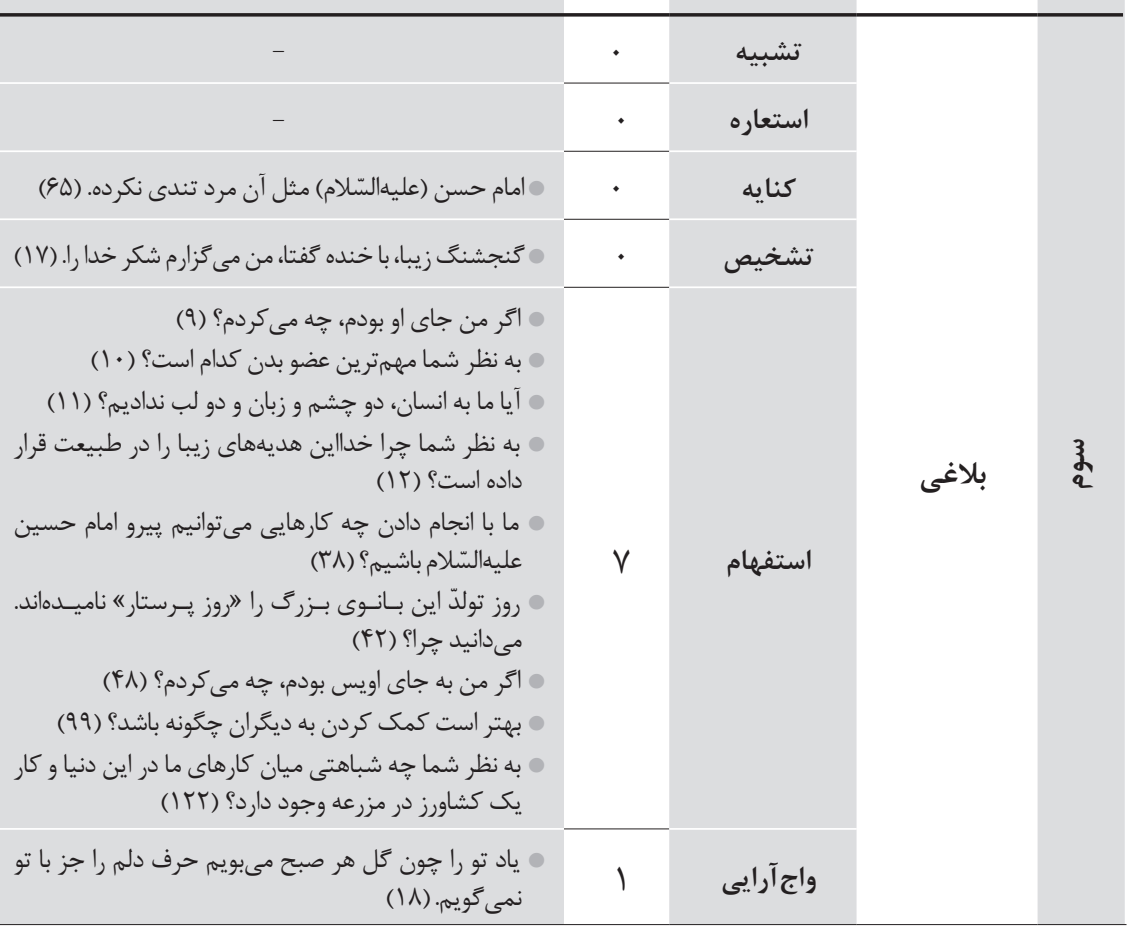


مطابق اطلاعات جدول F مؤلفهىايمان با فراوانى V|ز مجموع \| واحد تحليل شده بيشـــترين و مؤلفههاى آسمان و نيّت زيباى بشـــر با فراوانى ا، كمترين تكرار را دارند و به مؤلفههاى انســان، جانداران، طبيعت، رنتَ ها، مصنوعات هنرى بشر و عقل در كتاب

هديههاى آسمان :ايه سوم توجه نشده است. در زيبايىهاى بلاغى، استفهام با فراوانى 9 و واجآرايى با فراوانى ا و بقيه موارد بدون فراوانى مىباشند.

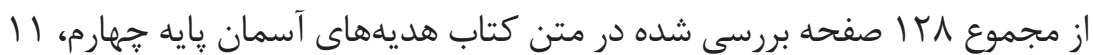
واحد تحليل شناســايى و فراوانى هر مؤلفه و كليدوازه مربوطه در جدول زير نشان داده شده است. در جدول ه فراوانى مؤلفهها و كليدوازههاى مؤلفهها با ذكر مثال براى هر كدام در يايه جهمارم آورده شده است.

جدول ه. جدول فراوانى مؤلفهها و كليد وازههاى زيبايیىشناسى

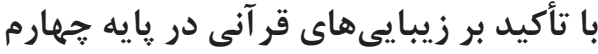

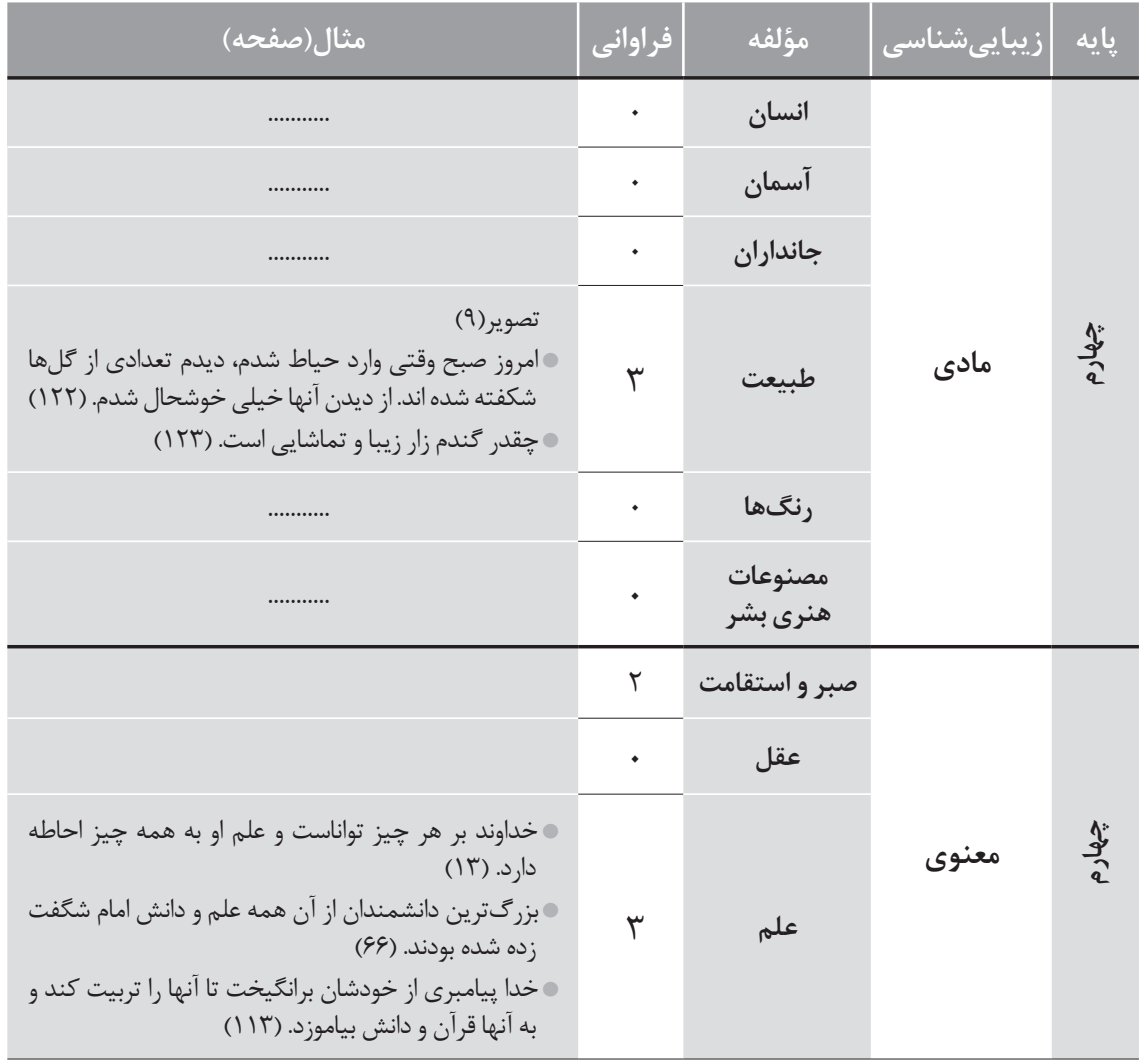


تحليل محتواى كتابهاى درسى دوره ابتدايى به لحاظ ميزان

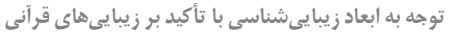

داود طهماسبزادهيخلار مآزاده صاحبىعلمدارى محسن ديبايىصابر

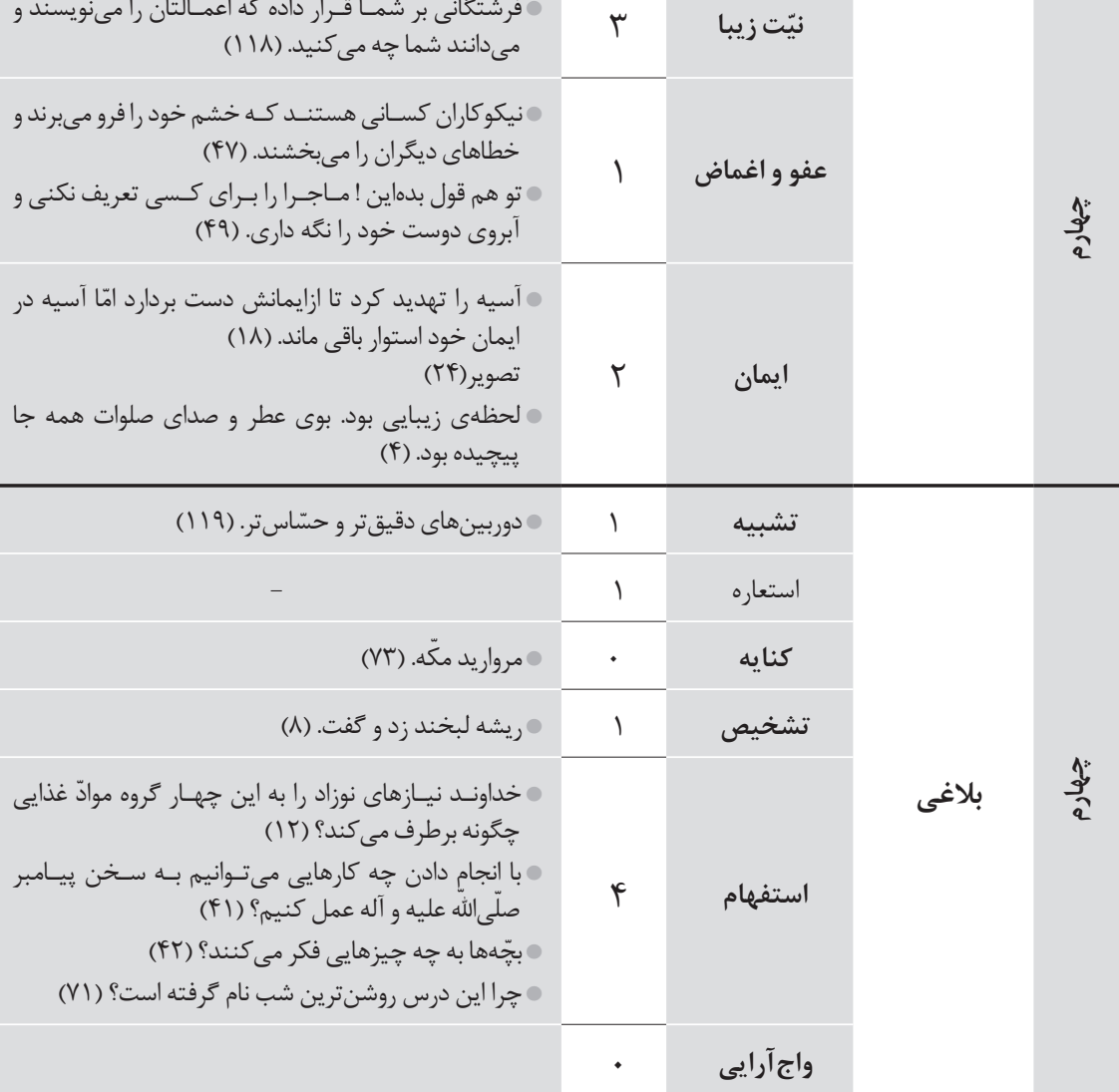

مطابق اطلاعات جدول ه مؤلفههاى طبيعت، علم و ايمان با فراوانى س از مجموع 11 واحد تحليل شــده بيشترين و مؤلفههاى نيّيت زيبا با فراوانى ا، كمترين تكرار را دارند و

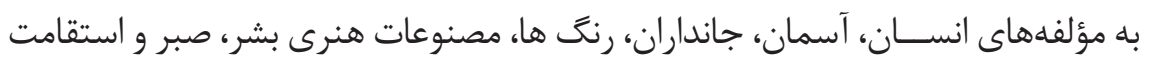
و عقل در كتاب هديههاى آســمان يايه جهارم توجه نشده است. در زيبايىهاى بلاغى،

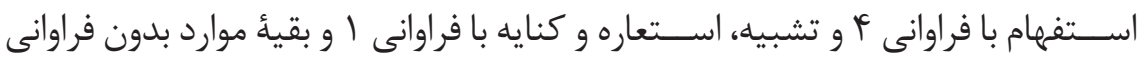
مىباشند.

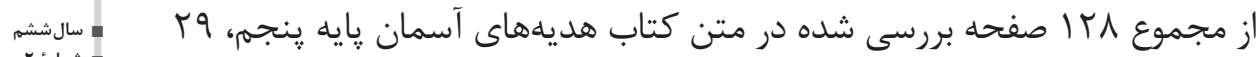


است. در جدول 4 فراوانى مؤلفهها و كليد وازمهاى مؤلفهها با ذكر مثال براى هر كدام در

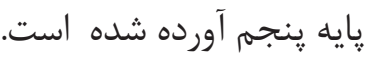

جدول 9. جدول فراوانى مؤلفهها و كليد وازههاى زيبايىشناسى با تأكيد بر زيبايى هاى قر آنى در هايه ينجم

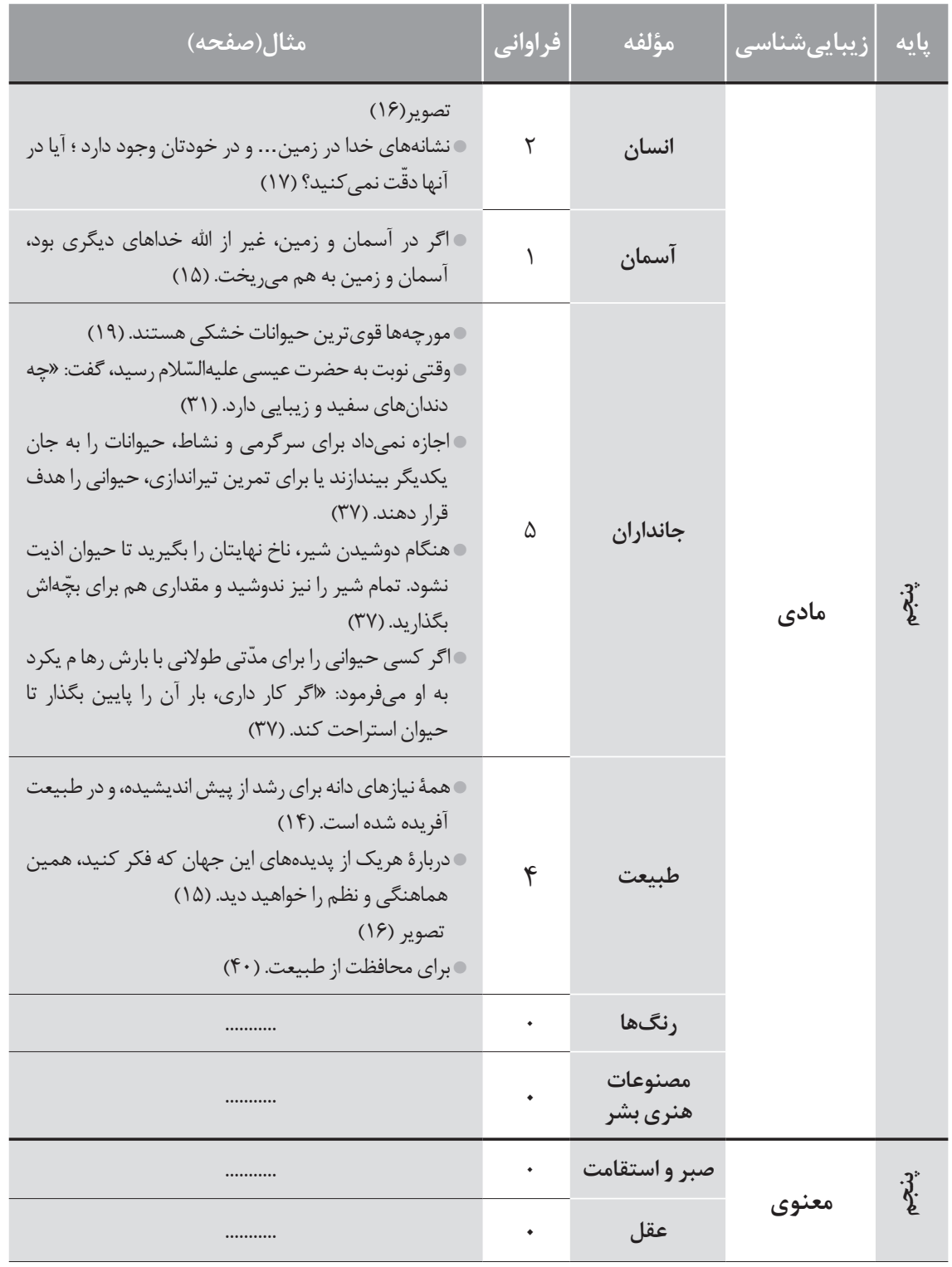


مطابق اطلاعات جدول و مؤلفهايمان با فراوانى V از مجموع 9r واحد تحليل شــده بيشـــرين و مؤلفههاى آسمان و نيّت زيباى بشـــر با فراوانى ا، كمترين تكرار را دارند و به مؤلفههاى رنتَها، مصنوعات هنرى بشر، صبر و استقامت و عقل در كتاب هديههاى آسمان يايه ينجم توجه نشده است. در زيبايىهاى بلاغى، استفهام با فراوانى ب و استعاره با فراوانى ب، تشبيه با فراوانى ا و بقيه موارد بدون فراوانى مىباشند. از مجموع | || صفحه بررسى شده در متن كتاب هديههاى آسمان קايه ششم، واحد تحليل شناســايى و فراوانى هر مؤلفه و كليدوازه مربوطه در جدول زير نشان داده شده است. در جدول V فراوانى مؤلفهها و كليدوازههاى مؤلفهها با ذكر مثال براى هر كدام در يائُ ششم آورده شده است.

جدول V. جدول فراوانى مؤلفهها و كليد وازههاى زيبايیىشناسى

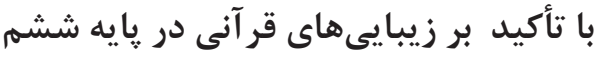

\begin{tabular}{|c|c|c|c|c|}
\hline مثال(صفحها) & فراوانى & مؤلفه & زيبايىشناسى & هايه \\
\hline$\ldots \ldots \ldots . .$. & - & انسان & \multirow[t]{6}{*}{ مادى } & \multirow{6}{*}{$: 3$} \\
\hline$\ldots \ldots \ldots \ldots$ & - & آسمان & & \\
\hline .............. & - & جانداران & & \\
\hline \multirow[t]{3}{*}{ 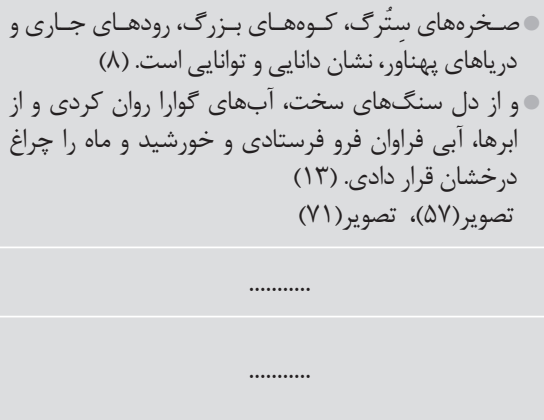 } & p & طبيعت & & \\
\hline & - & رنَها & & \\
\hline & - & هنرى بشنر & & \\
\hline ............... & - & صبر و استقامت & \multirow{3}{*}{ معنوى } & \multirow{3}{*}{ :3 } \\
\hline$\ldots \ldots \ldots \ldots$ & - & عقل & & \\
\hline 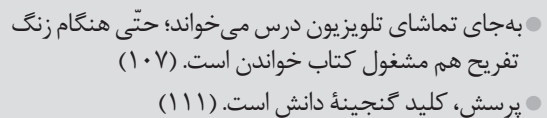 & r & علم & & \\
\hline
\end{tabular}


تحليل محتواى كتابهاي درسى دوره ابتدايى به لحاظ ميزان

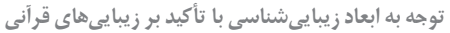

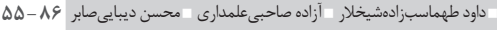

جدول V. (ادامه)

\begin{tabular}{|c|c|c|c|c|}
\hline مثال(صفحه) & فراوانى & مؤلفه & زيبايىشناسى & هايه \\
\hline 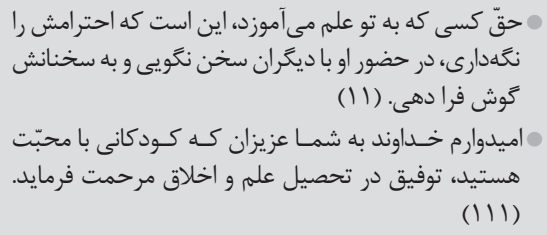 & f & علم & & \\
\hline 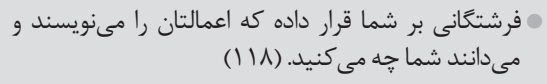 & r & نيّت زيبا & & \\
\hline 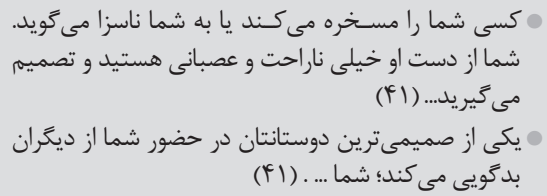 & r & عفو و اغماض & & 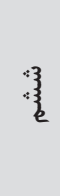 \\
\hline 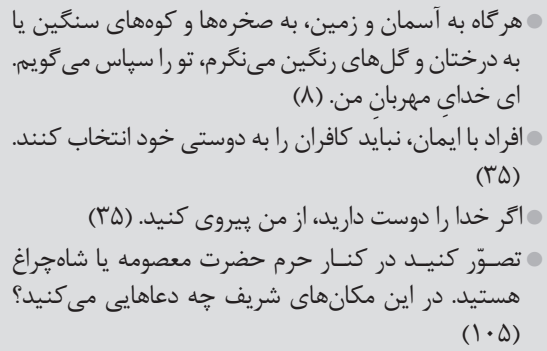 & f & ايمان & & \\
\hline
\end{tabular}

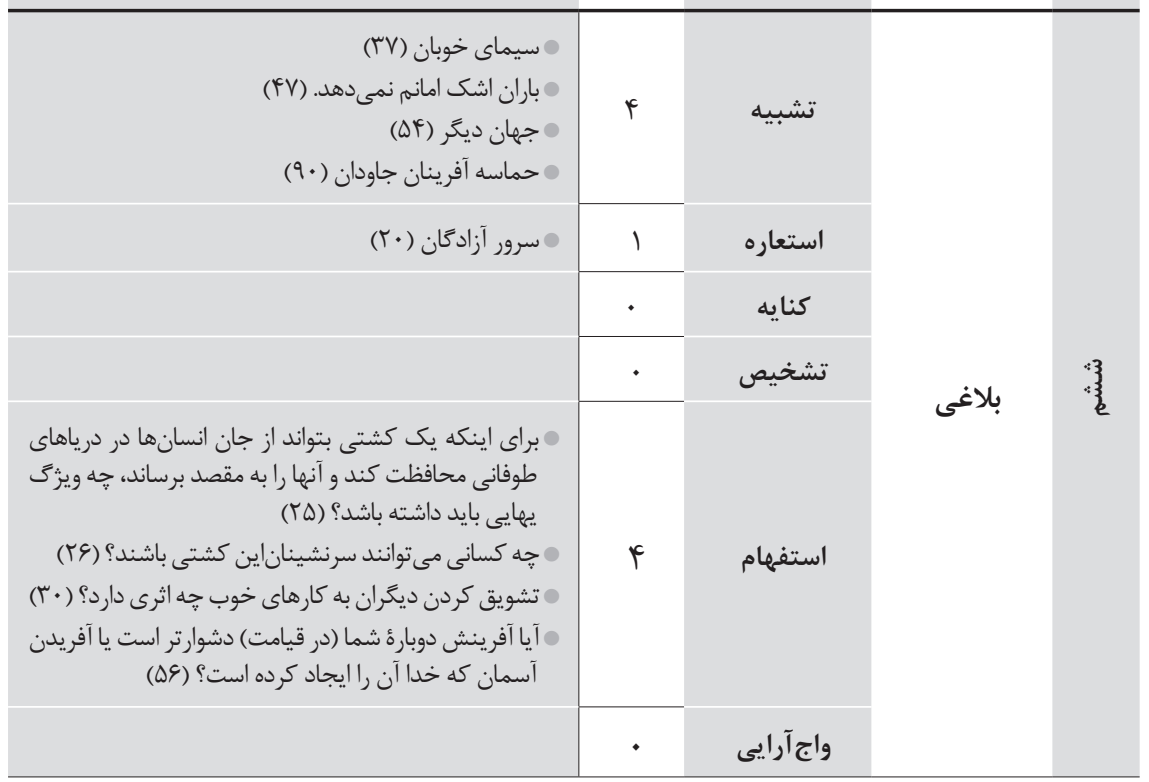


مطابق اطلاعات جدول V مؤلفههاى طبيعت، علم وايمان با فراوانى f از مجموع f ا واحد

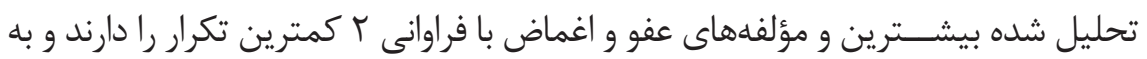
بقيه مؤلفهها در كتاب هديههاى آسمان يايه ششم توجه نشده است. در زيبايىهاى بلاغى، استفهام و تشبيه با فراوانى أو استعاره با فراوانى او بقيه موارد بدون فراوانى مىباشند.

جدول ^. دادههاى به هنجار شده شاخصهاى مربوط به ابعاد و مؤلفههاى زيبايى شناسى مادى، معنوى و بلاغى در قر آن

\begin{tabular}{|c|c|c|c|c|c|c|c|}
\hline ريشبينى & شُشم & هِنجّم & جهائه & ذوايه & أَّايه & مؤلفه ها & نوع زيبايى \\
\hline$\%$ & $\% F / \Delta F$ & $\% F$ & $\% / \mathrm{V}$ & $\% 1 / 19$ & $1.919 \mathrm{~V}$ & انسان & \multirow{6}{*}{ زيبايى } \\
\hline$\%$ & $\% / T / T V$ & $\% 14$ & • & • & $1.919 \mathrm{~V}$ & آسمان & \\
\hline$\% \varphi^{q}$ & $\% / T / T V$ & · & $\% / V$ & $\% 1 / 19$ & $1.919 \mathrm{~V}$ & جانداران & \\
\hline$\% q$ & . & $\%$. & $\% / /^{q}$ & $\% / \mathrm{VV}$ & سז,r.ז\% & طبيعت & \\
\hline$\% \varphi^{k}$ & • & $\% q$ & $\% / /^{\mathcal{F}}$ & $\% / 0 / 94$ & $1.919 \mathrm{~V}$ & رنغها & \\
\hline$\%$ & · & $\% \varphi^{4}$ & $\% / /^{q}$ & $\% / .499$ & $1.919 \mathrm{~V}$ & هنرى بشرعر & \\
\hline$\% \varphi^{q}$ & $\% / T / T V$ & · & $\% / /^{\mathcal{L}}$ & $\% / \mathrm{VV}$ & سז/ז/\% & استقامت & \multirow{6}{*}{ زيبايى } \\
\hline$\% .9$ & $\% / T V$ & $\% q$ & · & $\% 1 / 19$ & • & عقل & \\
\hline$\%$ & $\% .9 / \mathrm{AT}$ & • & $\% / \mathrm{N}$ & $\% / \Delta / 49$ & • & علم & \\
\hline$\% .9$ & $\% .8 / \mathrm{AT}$ & $\%$. & $\% / V$ & • & سז/ז/\% & نيّت زيبا & \\
\hline$\%$ & $\% F / \Delta F$ & $\% q$ & • & $\% / \mathrm{VV}$ & سז/ז/\% & اغماض و & \\
\hline$\% .9$ & $\% F / \Delta F$ & $\% q$ & • & $\% / r V$ & $1.919 \mathrm{~V}$ & ايمان & \\
\hline$\%$ & $\% .9 / \Lambda T$ & $\%$. & . & $\% / \mathrm{VV}$ & $1.919 \mathrm{~V}$ & تشبيه & \multirow{6}{*}{ زيباغيى } \\
\hline$\%$ & $\% F / \Delta F$ & $\% q$ & $\% / \mathrm{V}$ & $\% / \mathrm{rV}$ & سז/\%ץ\% & استعاره & \\
\hline$\%$ & $\% F / \Delta F$ & $\% F$ & $\% / \mathrm{V}$ & $\% / \Delta / \varphi q$ & $1.919 \mathrm{~V}$ & كنايه & \\
\hline$\%$ & $\% F / Q F$ & · & $\% / \mathrm{V}$ & $\% / . / 49$ & $\% .919 \mathrm{~V}$ & تشخيص & \\
\hline$\% \varphi^{4}$ & $\% F / \Delta F$ & $\% F$ & $\% / \mathrm{V}$ & $\% / r V$ & $1.919 \mathrm{~V}$ & استفهام & \\
\hline$\% .9$ & $\% / T V$ & $\%$. 1 & $\% / V$ & • & سץ/ץ.\% & واجآرايى & \\
\hline
\end{tabular}


به منظور ياسخكَويى به اين سؤال كه توجه به ابعاد و مؤلفههاى زيبايىهاى مادى با

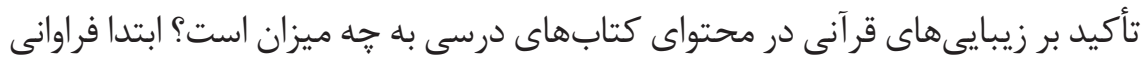

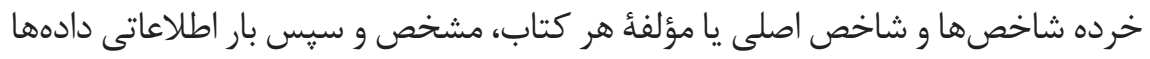

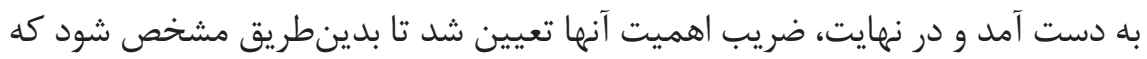
بيشترين ميزان توجه و اهميت به كدام مؤلفه تعلق دارد.

جدول 9: مقدار بار اطلاعاتى و ضريب اهميت مؤلفه زيبايىشناسى مادى

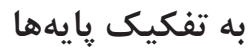
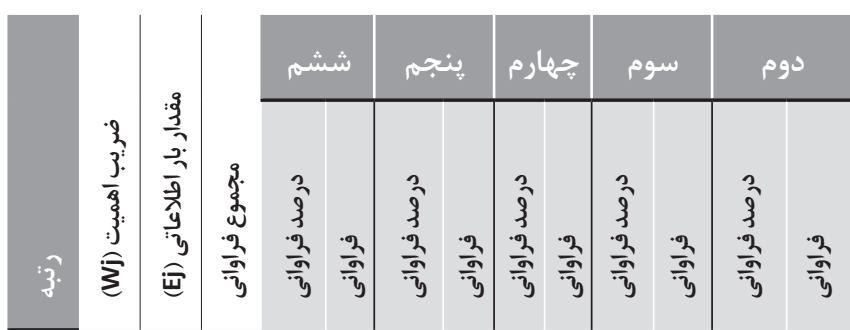

كليدوازه

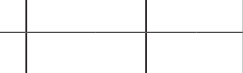

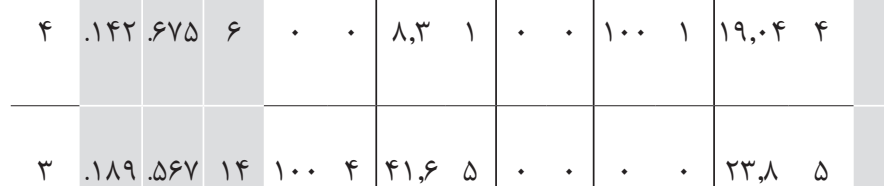

$$
\text { r. زيبايى آسمان }
$$

$r$

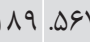

if ....

rr, a

r. زيبايى جانداران

3
3
$\vdots$
3
$y$
3
3
$y$

a ira.vir in

Fv, 1 .

f. زيبايى طبيعت y 
اطلاعات جدول 9 نشان مى دهد كه در كتاب هديههاى آسمان يايه دوم، آ مورد به زيبايىهاى مادى اشاره كرده كه بيشترين فراوانى مربوط به زيبايى طبيعت با فراوانى ل مورد و كمترين فراوانى مربوط به زيبايى مصنوعات هنرى بشر با فراوانى r مورد مىباشد.

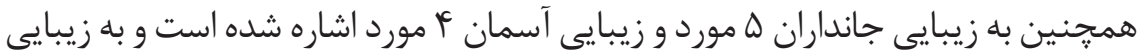
انسان و رنگَها در اين كتاب يرداخته نشده است. در كتاب هديههاى آسمان یايه سوم، ا مورد به زيبايىهاى مادى آن هم به زيبايى آســمان اشــاره شده و به ساير زيبايىها در اين كتاب ڤرداخته نشــده اســت. در كتاب هديههاى آسمان گايه جههارم، س مورد به زيبايىهاى مادى اشــاره شده كه زيبايى طبيعت بوده و به ساير زيبايىها در اين كتاب

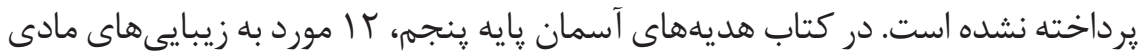
اشــاره شده كه بيشترين فراوانى مربوط به زيبايى جانداران با فراوانى ه مورد و كمترين

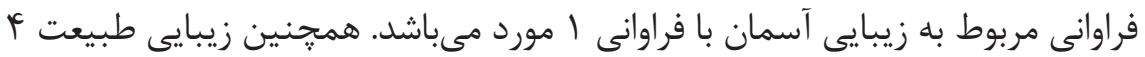

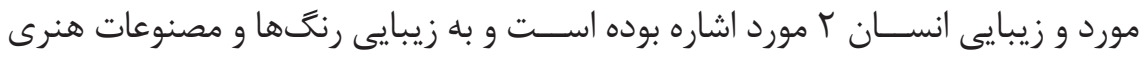
بشردر اين كتاب گرداخته نشده است. در كتاب هديههاى آسمان يايه ششم، أ مورد به زيبايىهاى مادى اشاره شده كه آن هم زيبايى جانداران بوده و به ساير زيبايىها در اين

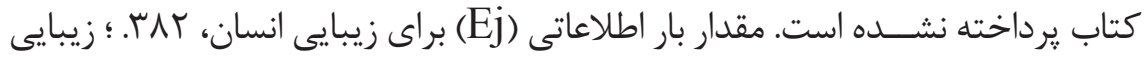

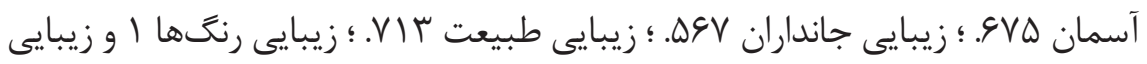

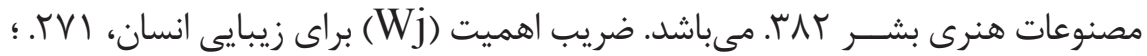

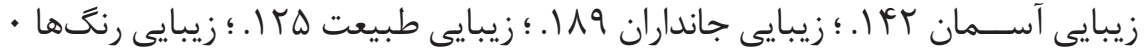
و زيبايى مصنوعات هنرى بشر IVI. مىباشد. رتبه بر اساس ضريب اهميت داده شده به هر يك از زيبايىها به شرح زير است كه: زيبايى انسان رتبه ل؛؛ زيبايى مصنوعات هنرى

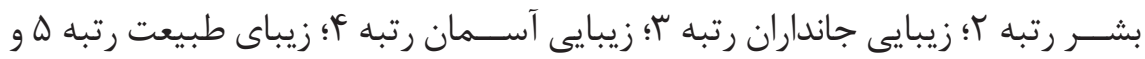
زيبايى رنگها رتبه 9 مىباشند. براى ياسخ به اين سؤال كه توجه به ابعاد و مؤلفههاى زيبايىهاى معنوى با تأكيد بر زيبايىهاى قرآنى در محتواى كتابهاى درســى به جهه ميزان است؟ ابتدا فراوانى خرده شــاخصها و شاخص اصلى يا مؤلفهُ هر كتاب، مشخص و سيس بار اطلاعاتى دادهها به دســت آمد و در نهايت، ضريب اهميت آنها تعيين شد تا بدين طريق مشخص شود كه 
تحليل محتواى كتابهاى درسى دوره ابتدايى به لحاظ ميزان

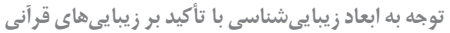

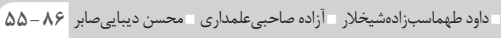

جدول •1. مقدار بار اطلاعاتى و ضريب اهميت مؤلفه زيبايىشناسى معنوى به تفكيك يايهها

\begin{tabular}{|c|c|c|c|c|c|c|c|c|c|c|c|c|c|c|c|}
\hline \multirow[b]{2}{*}{ ?. } & \multirow[b]{2}{*}{ 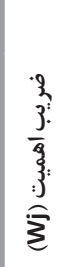 } & \multirow{2}{*}{ 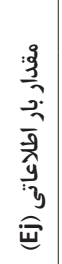 } & \multirow[b]{2}{*}{$\begin{array}{l}\frac{3}{9} \\
\frac{5}{4} \\
\frac{2}{2} \\
\frac{2}{3}\end{array}$} & \multicolumn{2}{|c|}{ ششم } & \multicolumn{2}{|c|}{ بنجم } & \multicolumn{2}{|c|}{ جهارم } & \multicolumn{2}{|c|}{ سوم سوم } & \multicolumn{2}{|c|}{ دوم } & & \\
\hline & & & & $\begin{array}{l}\hat{2} \\
\hat{3} \\
\frac{2}{2} \\
\frac{2}{3}\end{array}$ & $\frac{2}{-3}$ & $\begin{array}{l}\hat{3} \\
\frac{3}{3} \\
\frac{2}{2} \\
\frac{3}{3}\end{array}$ & $\frac{2}{9}$ & $\begin{array}{l}\hat{3} \\
3 \\
\frac{3}{2} \\
\frac{2}{3}\end{array}$ & $\frac{2}{-3}$ & $\begin{array}{l}\hat{3} \\
\frac{3}{3} \\
\frac{2}{\sqrt{3}}\end{array}$ & $\frac{2}{\frac{2}{3}}$ & $\begin{array}{l}\hat{3} \\
\frac{3}{3} \\
\frac{2}{\sqrt{3}}\end{array}$ & $\frac{2}{-3}$ & كليدوازه & $\frac{9}{9}$ \\
\hline 1 & וזr. & $.9 \% \wedge$ & f & - & . & . & . & • & - & $11, \mathrm{~V}$ & r & $V, \varphi^{f}$ & r & ا. صبر و استقامت & \\
\hline 4 & . & 1 & . & . & . & - & . & - & . & . & . & . & . & r. زيبايى عقل & \\
\hline$r$ & .114 & 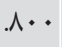 & IV & f. & r & $r q, r$ & $\Delta$ & 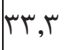 & r & $r q, r$ & $\Delta$ & - & - & r. ز. زيبايى علم & 3 \\
\hline r & $.49 F$ & $.9 \vee \wedge$ & 1. & $\cdot$ & $\Delta, \Lambda$ & אי, שr & 1 & 11,1 & 1 & $\Delta, \Lambda$ & 1 & $r \Delta, q$ & v & F. زيبايى طبيعت & 3 \\
\hline$\Delta$ & $\cdot V^{f}$ & .911 & 11 & $r$. & r & Tr, & r & TY, T & r & $11, \mathrm{~V}$ & r & $r, \mathrm{r}$ & 1 & ه. زيبايى عفو و & \\
\hline f & .110 &.$\Lambda V^{c}$ & rی & f. & c & 41,1 & V & א,ז" & r & $|F|, 1$ & v & sr, 9 & IV & צ. زيباييىايمان & \\
\hline & & & ᄉ. & $1 \cdots$ & 1 . & $1 \cdots$ & IV & $1 \cdots$ & 9 & $1 \cdots$ & IV & $1 \cdots$ & TV & جمع & \\
\hline
\end{tabular}

اطلاعات جدول • ا نشان مى دهد كه در كتاب هديههاى آسمان קايه دوم، VV مورد

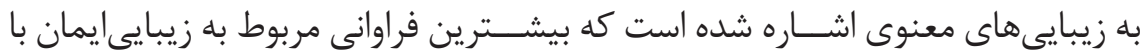

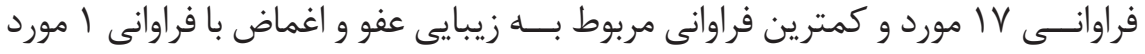

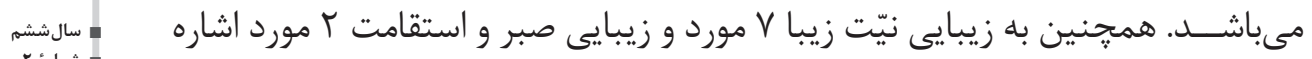

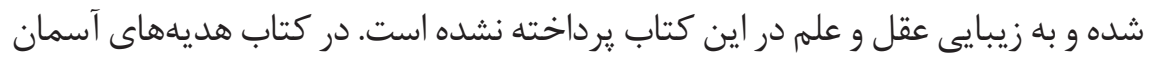


يايه سوم، VIV مورد به زيبايىهاى معنوى اشاره شده كه بيشترين فراوانى مربوط به زيبايى ايمــان با فراوانى V مـــورد و كمترين فراوانى مربوط به زيبايى نيّت زيبا با فراوانى ا مورد

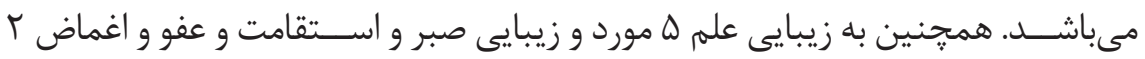
مورد اشــاره شده و به زيبايى عقل در اين كتاب زيرداخته نشده است. در كتاب هديههاى آسمان קايه جهارم، 9 مورد به زيبايى هاى معنوى اشاره شده كه بيشترين فراوانى مربوط به زيبايىايمان و علم با فراوانى س مورد و كمترين فراوانى مربوط به زيبايى نيّت زيبا با فراوانى ا مورد مىباشد. همجٍنين به زيبايى عفو و اغماض r مورد اشاره شده و به زيبايى صبر و استقامت و عقل در اين كتاب يرداخته نشده است. در كتاب هديههاى آسمان پايه ينجم، IV مورد به زيبايىهاى معنوى اشاره شده كه بيشترين فراوانى مربوط به زيبايىايمان با فراوانى V مورد و كمترين فراوانى مربوط به زيبايى نيّت زيبا با فراوانى ا مورد مىباشــــ.

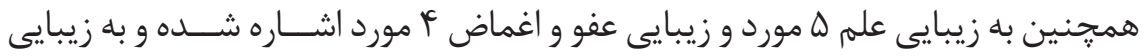
صبر و استقامت و عقل در اين كتاب يرداخته نشده است. در كتاب هديههاى آسمان يايه ششــه، • ا مورد به زيبايىهاى معنوى اشاره شده كه بيشترين فراوانى مربوط به زيبايى علم وايمان با فراوانى ع مورد و كمترين فراوانى مربوط به زيبايى عفو و اغماض با فراوانى ك مورد مىباشــد؛ در صورتى كه به زيبايى صبر و اســتقامت، عقـلـ و نيّت زيبا در اين

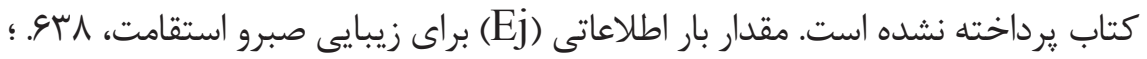

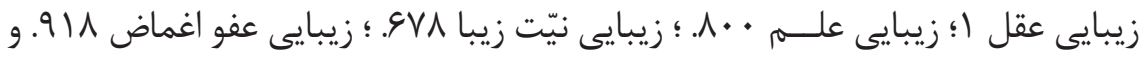
زيبايىايمان AVF. مى باشـــ. ضريب اهميت (Wj) براى زيبايى صبرو استقامت، اسب. ؛

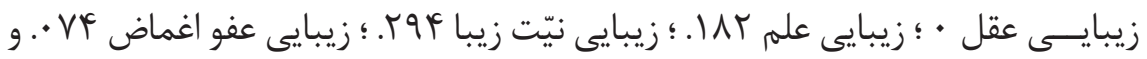
زيبايىايمان ها ا ا. مىباشد. رتبه بر اساس ضريب اهميت داده شده به هر يك از زيبايىها به شرح زير است كه: زيبايى صبر و استقامت رتبه |؛ زيبايى نيّت زيبا رتبه ب؛ زيبايى علم

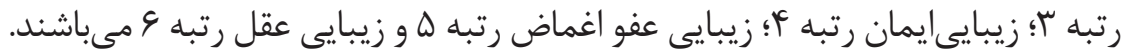
براى ياسخ به اين سؤال كه توجه به زيبايىهاى بلاغى قرآنى (تشبيه، استعاره، كنايه، تشــخيص، اســتفهام، واجآرايى) در محتواى كتابهاى درسى به جه ميزان است؟ ابتدا فراوانى خرده شاخصها و شاخص اصلى يا مؤلفهُ هر كتاب، مشخص و سيس بار اطلاعاتى دادهها به دســت آمد و در نهايت، ضريب اهميت آنها تعيين شد تا بدين طريق مشخص شود كه بيشترين ميزان توجه و اهميت به كدام مؤلفه تعلق دارد. 
تحليل محتواى كتابهاى درسى دوره ابتدايى به لحاظ ميزان

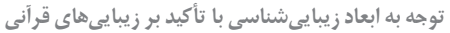

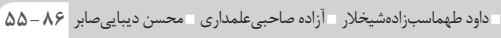

جدول Iا. مقدار بار اطلاعاتى و ضريب اهميت مؤلفه زيبايىشناسى مادى

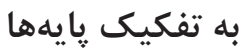

\begin{tabular}{|c|c|c|c|c|c|c|c|c|c|c|c|c|c|c|c|}
\hline \multirow[b]{2}{*}{3} & \multirow[b]{2}{*}{\begin{tabular}{c}
3 \\
$\frac{3}{3}$ \\
$\frac{3}{3}$ \\
$\vdots$ \\
\hdashline
\end{tabular}} & \multirow{2}{*}{ 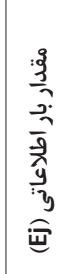 } & \multirow[b]{2}{*}{$\begin{array}{l}\frac{3}{3} \\
\frac{5}{2} \\
\frac{2}{2} \\
\frac{2}{3}\end{array}$} & \multicolumn{2}{|c|}{ ششم } & \multicolumn{2}{|c|}{ ينجم } & \multicolumn{2}{|c|}{ جهارم } & \multicolumn{2}{|c|}{ سوم } & \multicolumn{2}{|c|}{ دوم } & \multirow[b]{2}{*}{ كليدوازه } & \multirow[b]{2}{*}{$\frac{4}{3}$} \\
\hline & & & & $\begin{array}{l}\hat{3} \\
3 \\
\frac{2}{9} \\
\frac{3}{3}\end{array}$ & $\frac{2}{\frac{2}{3}}$ & $\begin{array}{l}\hat{3} \\
3 \\
\frac{2}{2} \\
\frac{2}{3}\end{array}$ & $\frac{2}{-3}$ & $\begin{array}{l}\hat{3} \\
3 \\
\frac{2}{9} \\
\frac{3}{3}\end{array}$ & $\frac{2}{-3}$ & $\begin{array}{l}3 \\
\frac{3}{3} \\
\frac{2}{2} \\
\frac{3}{3}\end{array}$ & $\frac{2}{\frac{2}{3}}$ & $\begin{array}{l}\frac{3}{3} \\
\frac{3}{2} \\
\frac{2}{3}\end{array}$ & $\frac{2}{\frac{2}{3}}$ & & \\
\hline 1 &.$r \cdot r$ & $\wedge \vee \wedge$ & 4 & $F F, F$ & i & 19,9 & 1 & $\mid f, r$ & 1 & • & • & • & • & ا. تشبيه & \\
\hline r &.$I \vee \wedge$ & .949 & f & $11, r$ & 1 & | & $r$ & $\mid f, r$ & · & . & - & - & . & ז. استعاره & \\
\hline r & $.1 \cdots$ & .999 & 1 & . & . & - & . & - & . & • & • & $\mid f, Y$ & - & ". كنايه & 3 \\
\hline r & $.1 \cdots$ & .999 & 1 & . & . & . & . & $\mid f, r$ & 1 & . & - & - & - & F. تشخيص & y \\
\hline r & .110 & .990 & re & $F F, F$ & r & $\Delta \cdot$ & r & $\Delta V, 1$ & r & 9. & 9 & $\wedge \downarrow, \wedge$ & 4 & ه. استفهام & \\
\hline r & $.1 \cdots$ & .999 & 1 & - & 1 & . & 1 & . & - & 1. & 1 & - & - & و. واجآرايى & \\
\hline & & & rq & $1 \cdots$ & 9 & $1 \cdots$ & 9 & $1 \cdots$ & V & $1 \cdots$ & 1. & $1 \cdots$ & V & جمع & \\
\hline
\end{tabular}

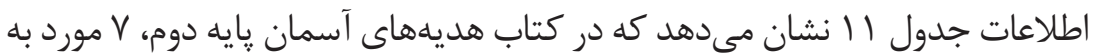
زيبايىهاى بلاغى قرآنى اشاره شده كه بيشترين فراوانى مربوط به استفهام با فراوانى 9

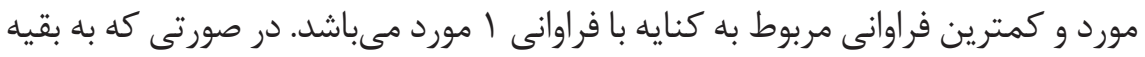

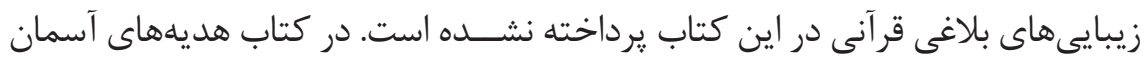

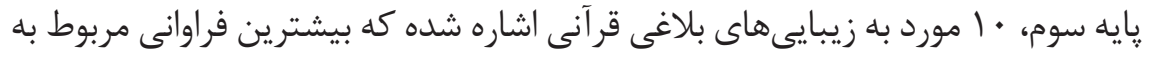


و به بقيه زيبايىهاى بلاغى قرآنى در اين كتاب يرداخته نشــده است. در كتاب هديههاى

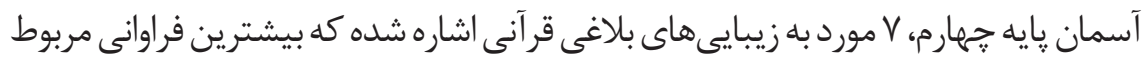

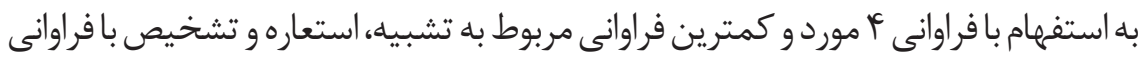
1 ا مورد مىباشــد و به بقيه زيبايىهاى بلاغى قرآنى در اين كتاب ترداخته نشده است. در

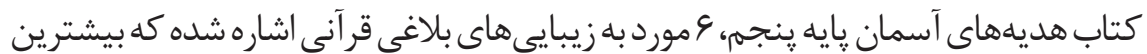

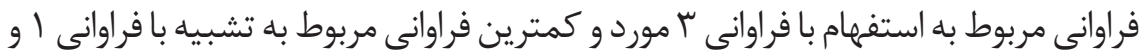

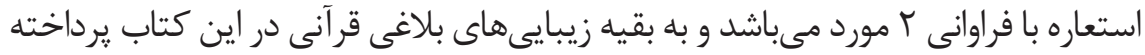

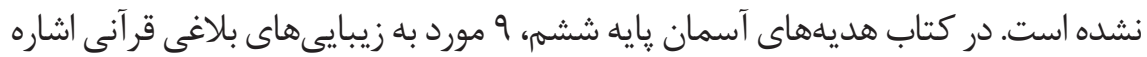

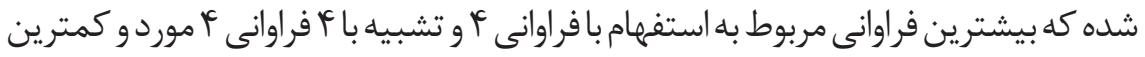

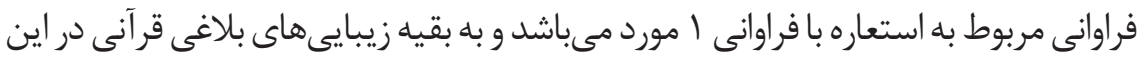

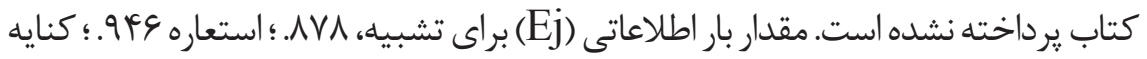

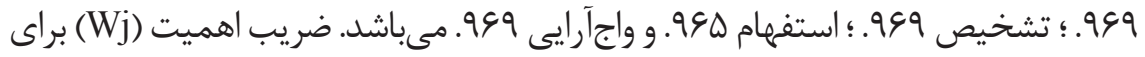

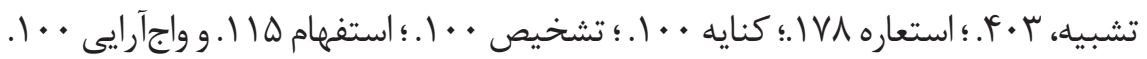

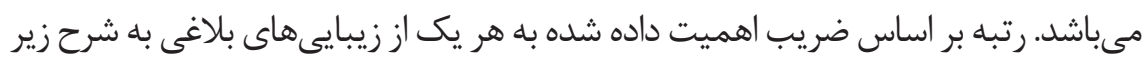

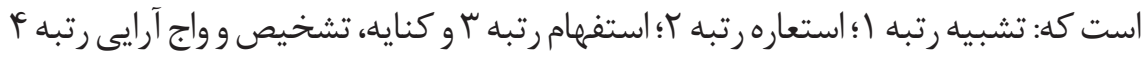
مى مباشند.

\section{بحتق و نتنبيجلَّيرى}

يزوهش حاضر با هدف تحليل محتواى كتابهاى درسى به لحاظ ميزان توجه به ابعادو

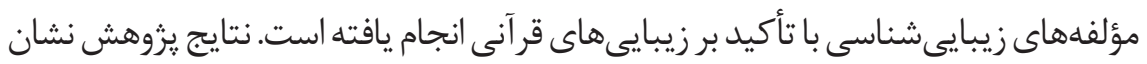

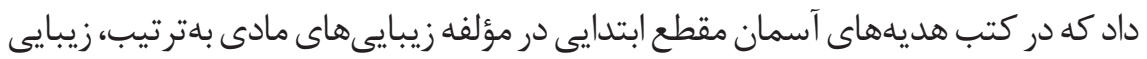

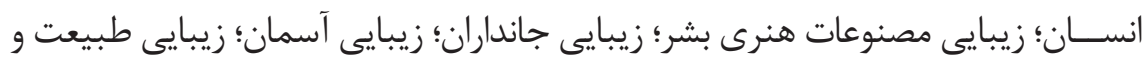

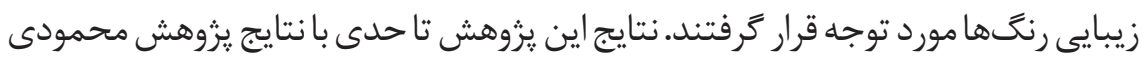

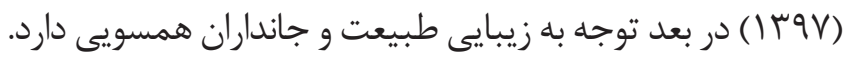

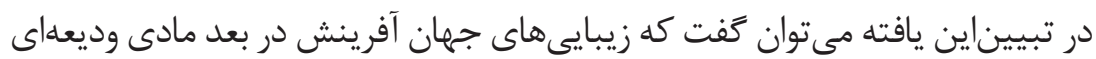

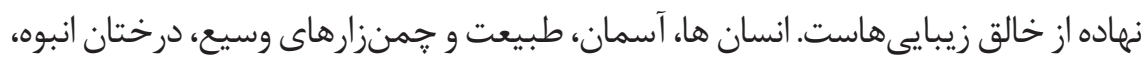

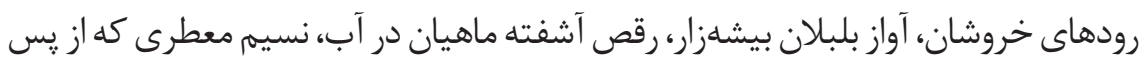


نيزار مىوزد، آشكارا فرياد مىزند كه هنوز خداوند به انسان اميد دارد و ييوسته نشانههاى

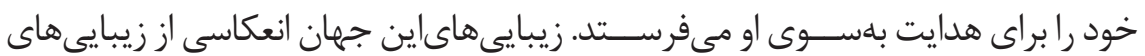
ذات ياك الهى است كه با شناخت درست آن مىتوان بينش و جهانبينى خود را بهسمت مفاهيهم و آموزههاى ناب الهى تغيير داد. از اين رو، كتاب هديههاى آســمان دوره ابتدائى بهعنوان يكى از كتابهاى اصلى در انتقال مفاهيم دينى و قرآنى، نقش به ســزايـى دارد و مفاهيم زيبايى قرآى بايد در متن و محتواىاين كتاب بهصورت مشـــودى نمايان شود تا زمينه را براى آشنايى دانش آموزان با اين مفاهيم زيبا فراهم سازد. نتايج يزوهش نشان داد كه در كتب هديلهاى آسمان مقطع ابتدايى در مؤلفه زيبايى هاى معنوى به ترتيب، زيبايى صبر و اســتقامت؛ زيبايى نيّــت زيبا؛ زيبايى علم؛ زيبايىايمان؛ زيبايى عفو اغماض و زيبايى عقل مورد توجه قرار گرفتهاند. نتايج اين يزوهش تا حدى با

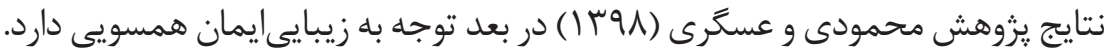
در تبيين اين يافته مىتوان كفت كه بى ترديد يكى از اهداف رسالت، سوق دادن انسان بهسوىاين زيبايى هاى معنوى مىباشد. ييامبر اعظم (صلى الله عليه و اله و سلم مىفرمايند:

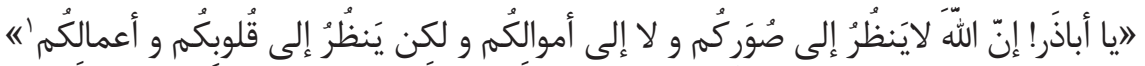
(الأمالى، طوسى: عسه). همجنين يِامبر اكرم حضرت محمد (صلى الله عليه و آله) در جواب إبى

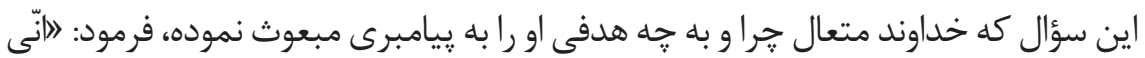

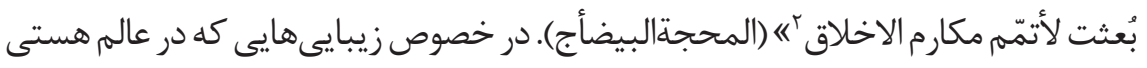
وجود دارد، هر جند زيبايى هاى مادى در اسلام داراى ارزش و جايگاه بالايى مىباشند، ولى در نهايت اين زيبايىهاى معنوى هســتند كه انسان را به مقامات اعلى و انسانى رهنمود مى كند. در واقع انســان هر جند از زيبايىهاى ظاهرى و مادى برخوردار است ولى اتر در خصوص زيبايى هاى معنوى غفلت و كوتاهى كند، از سعادت و خوشبختى واقعى دور خواهد ماند. اصبر جميل" به معنى شكيبايى زيبا و قابل توجه است، و آن صبر و استقامتى است كه تداوم داشته باشد، يأس و نوميدى به آن راه نيابد، و توأم با بى تابى و جزع و شكوه و آه و ناله نكردد، و در غير اينصورت جميل نيست. صبر، گذشت، كناره گرفتن و جدا شدن نمونههايى از افعال انسان است كه گَونهاى زيبا و گَونهاى نازيبا دارد و قرآن كريم به نوع 
زيباى آن ســفارش مى كند. از اين رو، مفاهيم معنوى زيباى قرآنى نشانكر اهميت قائل

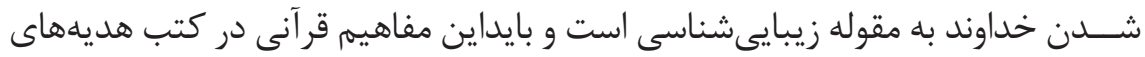

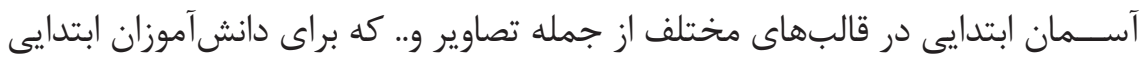

تأثير زيادى دارند، كَنجانده شوند.

نتايج يزوهش نشان داد كه در كتب هديههاى آسمان مقطع ابتدايى توجه بـه زيبايىهاى نداى

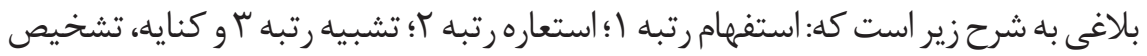

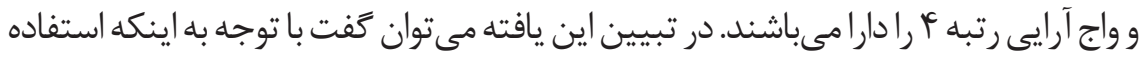

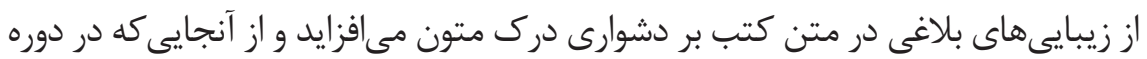

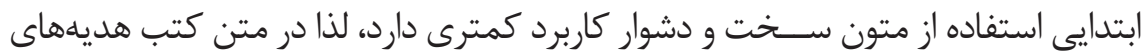

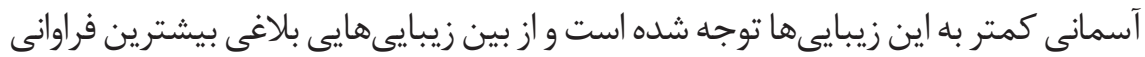

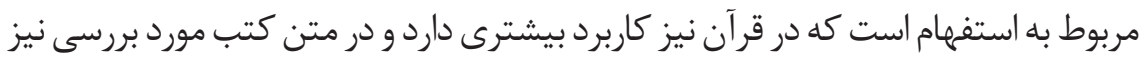

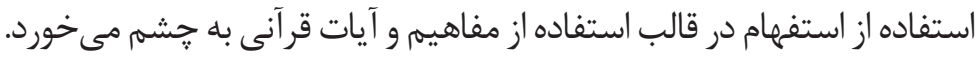

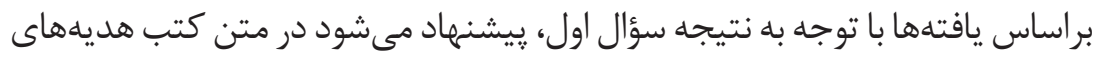

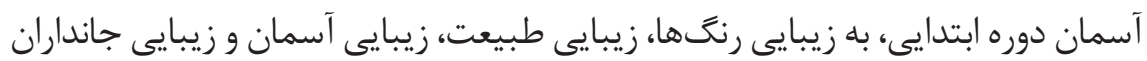

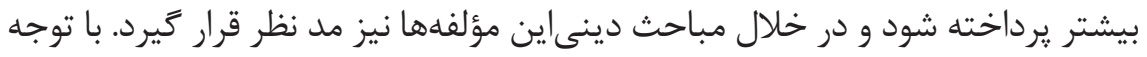

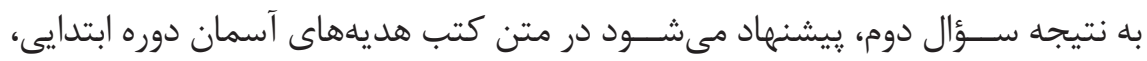

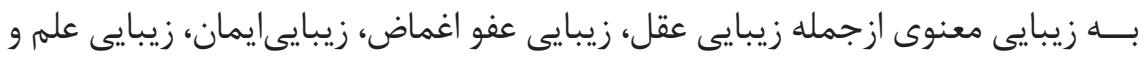

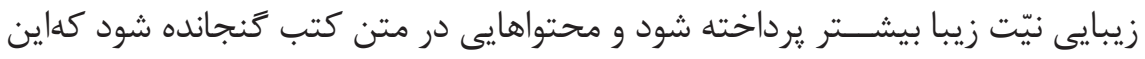

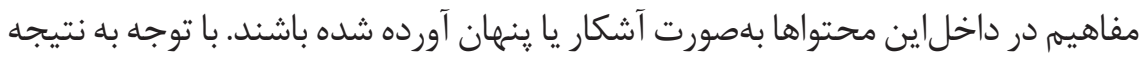

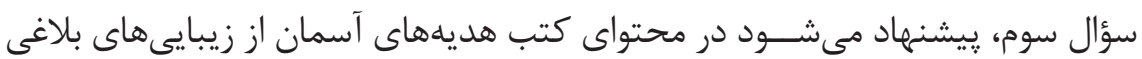
قرآنى استفاده بيشترى برده شود.

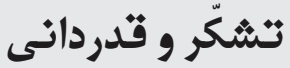

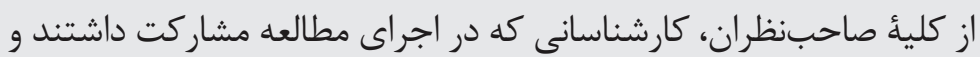

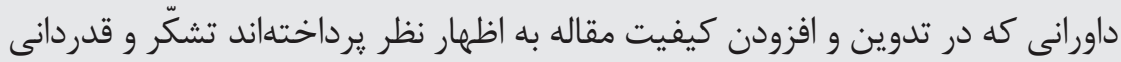
بلهمل مى آيد. 


\section{منابع}

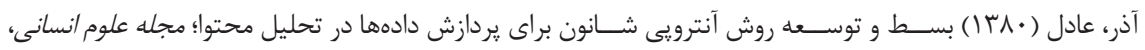

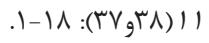

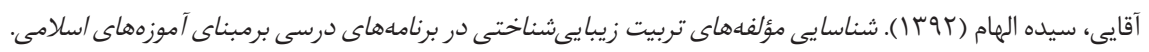

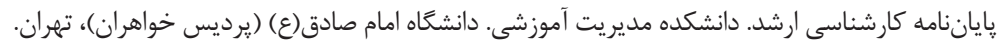

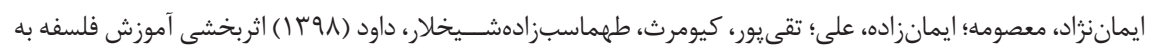

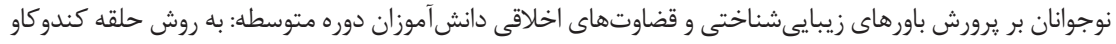

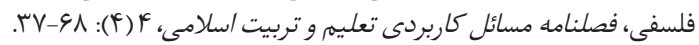

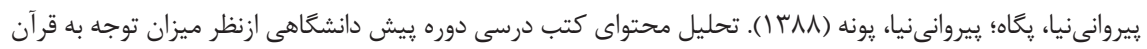

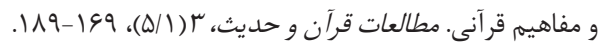

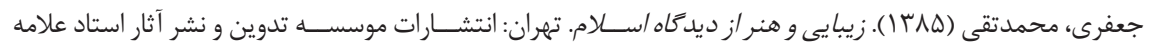
محمدتقى جعفرى.

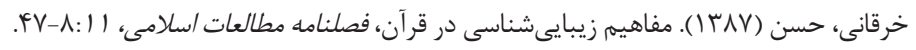

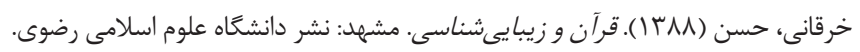

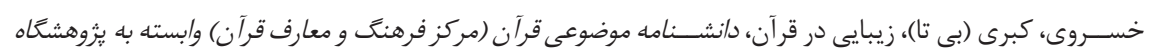

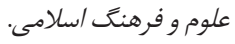

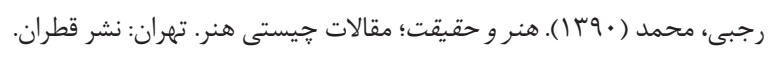

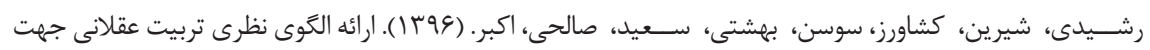

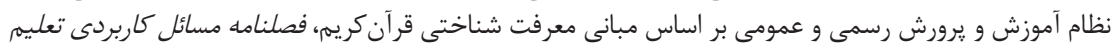

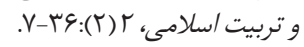

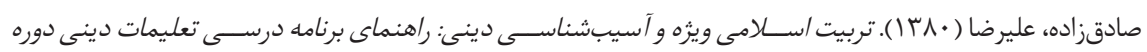

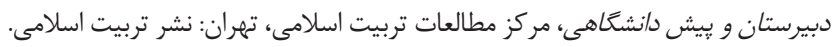

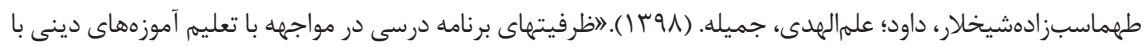

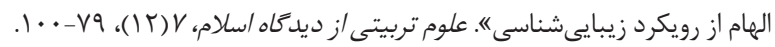

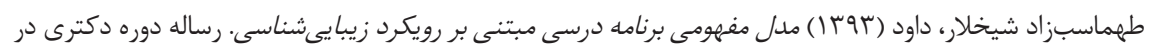

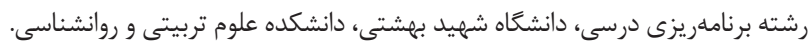

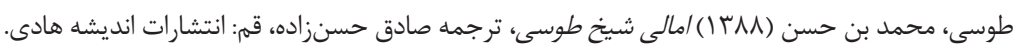

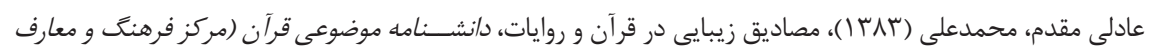

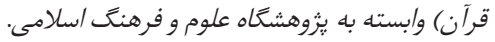

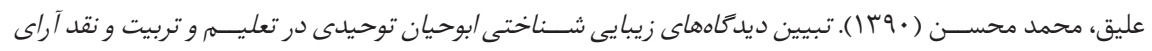

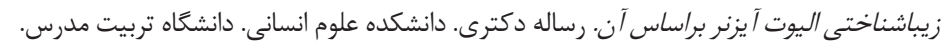

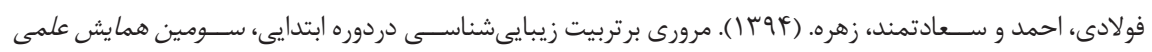

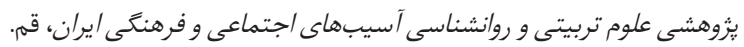

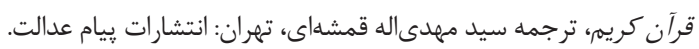

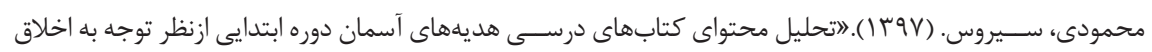

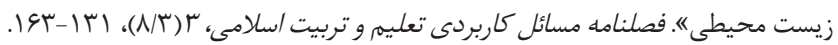

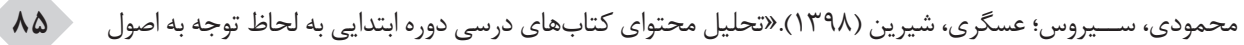

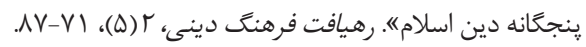




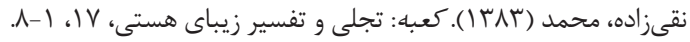

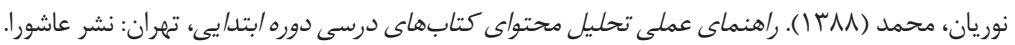

$$
\begin{aligned}
& \text { يارمحمديان، محمد حسين (• وب1). اصول و مبانى برنامهريزى درسى، تهران: انتشارات يادواره كتاب. }
\end{aligned}
$$

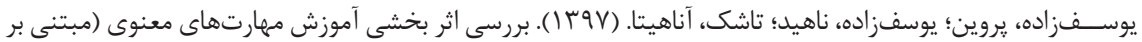

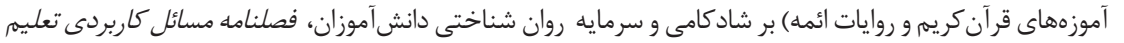

$$
\begin{aligned}
& \text { و تربيت /سلامى، }
\end{aligned}
$$

\section{REFERENCES}

Gale, R. (2005). Aesthetic literacy and the "living of lyrical moments". Journal of Cognitive Affective Learning, 2(1), pp.1-9.

Jacobs, R. (2009). Measuring aesthetic development: A national dialogue. Journal of Artistic and Creative Education, 3(1): 75-96.

Niemi, R. G. \& J. Junn. (1993), Civic sources and political knowledge of school: Seniors, aper presented at the annual meeting of American political science association, Washington, DC, September 2. 